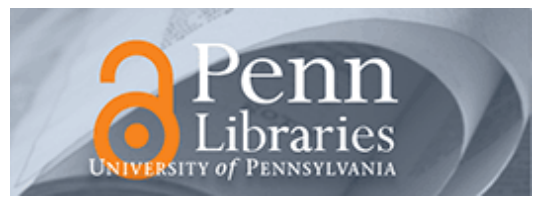

Manuscript Studies

Volume 3

Issue 2 Fall 2018

Article 1

2019

\title{
Notes of Exchange: Scribal Practices and Vernacular Religious Scholarship in Early Modern North India
}

Tyler Williams

University of Chicago, twwilliams@uchicago.edu

Follow this and additional works at: https://repository.upenn.edu/mss_sims

Part of the Medieval Studies Commons, and the South and Southeast Asian Languages and Societies Commons

\section{Recommended Citation}

Williams, Tyler (2019) "Notes of Exchange: Scribal Practices and Vernacular Religious Scholarship in Early Modern North India," Manuscript Studies: Vol. 3 : Iss. 2 , Article 1.

Available at: https://repository.upenn.edu/mss_sims/vol3/iss2/1

This paper is posted at ScholarlyCommons. https://repository.upenn.edu/mss_sims/vol3/iss2/1

For more information, please contact repository@pobox.upenn.edu. 


\title{
Notes of Exchange: Scribal Practices and Vernacular Religious Scholarship in Early Modern North India
}

\begin{abstract}
What happens when a vernacular language like Hindi begins to be committed to writing, entering the realm of a manuscript culture that was formerly monopolized by 'cosmopolitan' languages like Sanskrit, Arabic, and Persian? How did the pioneering vernacular intellectuals of Hindi adopt, adapt, combine, or challenge conventions and practices from existing Indic and Islamicate manuscript traditions? This paper examines manuscripts containing works of religious scholarship produced by two Hindu sects in seventeenth- and eighteenth-century North India in order to map intellectual networks, glean information about the training of religious scholars, reconstruct performative contexts, and refine our understanding of what distinguished "religious" scholarship in this time from other areas of enquiry, such as literary theory or philosophy. Using techniques of both 'close' and 'distant' reading on a corpus of approximately three hundred manuscripts, I outline the major features that distinguished manuscripts of vernacular scholarly works during the seventeenth and eighteenth centuries from manuscripts containing other types of text, highlighting those elements that reveal the shape of intellectual networks, the dynamics of performance contexts, and the role of paper manuscripts as notes or 'currency' of intellectual, social, and political exchanges. In the process, I offer reasons to re-examine commonly held scholarly assumptions about the religious literature and culture of this period.
\end{abstract}

\section{Keywords}

India, South Asia, Hindi, Sanskrit, Vernacularization, Religion, Literature, Scholarship, Early modern, Multilingual, Manuscript studies, close reading, distant reading, paper 


\section{MANUSCRIPT STUDIES}

A Journal of the Schoenberg Institute for Manuscript Studies

VOLUME 3, NUMBER 2

(Fall 2018)

Manuscript Studies (ISSN 2381-5329) is published semiannually

by the University of Pennsylvania Press

The Schoenberg Institute
for Manuscript Studies
University of Pennsylvania Libraries 


\title{
MANUSCRIPT STUDIES
}

\author{
VOLUME 3, N UMBER 2 \\ (Fall 2018)
}

\section{ISSN 2381-5329}

Copyright ( 2018 University of Pennsylvania Libraries and University of Pennsylvania Press. All rights reserved.

Published by the University of Pennsylvania Press, 3905 Spruce Street, Philadelphia, PA 19104.

Printed in the U.S.A. on acid-free paper.

Manuscript Studies brings together scholarship from around the world and across disciplines related to the study of premodern manuscript books and documents, with a special emphasis on the role of digital technologies in advancing manuscript research. Articles for submission should be prepared according to the Chicago Manual of Style, $16^{\text {th }}$ edition, and follow the style guidelines found at http://mss.pennpress.org.

None of the contents of this journal may be reproduced without prior written consent of the University of Pennsylvania Press. Authorization to photocopy is granted by the University of Pennsylvania Press for libraries or other users registered with Copyright Clearance Center (CCC) Transaction Reporting Service, provided that all required fees are verified with CCC and paid directly to CCC, 222 Rosewood Drive, Danvers, MA 01923. This consent does not extend to other kinds of copying for general distribution, for advertising or promotional purposes, for creating new collective works, for database retrieval, or for resale.

\section{SUBSCRIPTION INFORMATION:}

Single issues: $\$ 30$

Print and online subscriptions: Individuals: $\$ 40$; Institutions: $\$ 92$; Full-time Students: $\$ 30$ International subscribers, please add $\$ 18$ per year for shipping.

Online-only subscriptions: Individuals: $\$ 32$; Institutions: $\$ 80$

Please direct all subscription orders, inquiries, requests for single issues, address changes, and other business communications to Penn Press Journals, 3905 Spruce Street, Philadelphia, PA 19104. Phone: 215-573-1295. Fax: 215-746-3636. Email: journals@pobox.upenn.edu. Prepayment is required. Orders may be charged to MasterCard, Visa, and American Express credit cards. Checks and money orders should be made payable to "University of Pennsylvania Press" and sent to the address printed directly above.

One-year subscriptions are valid January 1 through December 31. Subscriptions received after October 31 in any year become effective the following January 1 . Subscribers joining midyear receive immediately copies of all issues of Manuscript Studies already in print for that year.

Postmaster: send address changes to Penn Press Journals, 3905 Spruce Street, Philadelphia, PA 19104.

Visit Manuscript Studies on the web at mss.pennpress.org. 


\section{MANUSCRIPT STUDIES}

A Journal of the Schoenberg Institute for Manuscript Studies

VOLUME 3 , NUMBER 2

\section{Articles}

Notes of Exchange: Scribal Practices and Vernacular

Religious Scholarship in Early Modern North India

Tyler Williams

Translating Machiavelli's Prince in Early Modern England:

New Manuscript Evidence

Alessandra Petrina

Provenance in the Aggregate: The Social Life of an Arabic

Manuscript Collection in Naples

Paul Love

Illuminated Leaves from an Ethiopic Gospel Book in the

Newark Museum and in the Walters Art Museum

JACOPO GNISCI

Re-Conceptualizing the Poems of the Pearl-Gawain

Manuscript in Line and Color

Maidie Hilmo

\section{Annotations}

A Codicological Assessment of Three Gospel Books with

Sideways-Oriented Illustrations Displayed in the

Metropolitan Museum of Art's Armenia Exhibition

ZsUZsANnA GULÁcsI

A Psalter from Maillezais at Maynooth

Peter J. Lucas and Angela M. Lucas 
iv | Journal for Manuscript Studies

A Dossier of Texts for the Augustinian Hermits of Lucca

Thomas M. IzBicki

Digitizing the University of Pennsylvania's Indic Manuscripts

Benjamin J. Fleming

Reviews

Kathryn M. Rudy. Piety in Pieces: How Medieval Readers

Customized Their Manuscripts

A. R. BennetT

Georgi R. Parpulov. Toward a History of Byzantine Psalters, ca. 850-1350 AD

Barbara Crostini

Corine Schleif and Volker Schier, eds. Manuscripts

Changing Hands

JoHAN OOSTERMAN

495

Nichols, Stephen G. From Parchment to Cyberspace:

Medieval Literature in the Digital Age

BRIDGET WHEARTY

499

List of Manuscripts Cited

505 


\title{
Notes of Exchange
}

\section{Scribal Practices and Vernacular Religious Scholarship in Early Modern North India}

\author{
Tyler Williams \\ University of Chicago
}

HIS ESSAY EXAMINES A corpus of manuscripts containing texts of
vernacular religious scholarship composed in the language of early
Hindi during the seventeenth and eighteenth centuries in order to reconstruct intellectual networks in northwestern India and to assess the role that paper manuscripts played in bringing those networks into being. ${ }^{1}$ I use the concept of "exchange" as an analytic through which to understand several aspects of the production, circulation, and reception (or performance) of these manuscripts, which contained works of theology,

I would like to thank Lynn Ransom, Benjamin Fleming, and the patrons and staff of the Schoenberg Symposium on Manuscript Studies in the Digital Age for the opportunity to present an earlier version of this paper at the Symposium's tenth meeting, "Intertwined Worlds," held 2-4 November 2017. I learned a tremendous amount from the various participants' feedback, questions, and presentations. I also thank the two anonymous reviewers for their very helpful comments and suggestions.

1 I use the term "Hindi" to refer to the literary register of those vernacular languages of North India that, during the period under consideration in this essay, were collectively called Hindi, Hindavi, $b h \bar{a} s \bar{a}$, or $b b \bar{a} k b \bar{a}$, and that today often bear distinct names like Avadhi, Brajbhasha, Maithili, and Marwari. As Imre Bangha has argued, despite the heterogeneity of spoken dialects across the rather large geographical expanse of North India, the literary register used in vernacular texts was broadly intelligible across geographic and generic lines, and therefore should be treated as a single entity for the purposes of literary history. See his article "The Emergence of Hindi Literature: From Transregional Maru Gurjar to Madhyadeśī Narratives," in Text and Tradition in Early Modern North India, ed. Tyler Williams, Anshu Malhotra, and John S. Hawley (New Delhi: Oxford University Press, 2018), 3-39. This roughly corresponds to Sheldon Pollock's notion of the "cosmopolitan vernacular" (for Pollock's theory of vernacularization, see below). 
philosophy, commentary, and translation. Ultimately, the fact that religious discussions took place on and through the medium of paper manuscripts at this place and time means that intellectual "exchange" always entailed the exchange of material things as well as the exchange of ideas. ${ }^{2}$

By identifying what distinguished manuscripts of vernacular "scholarship" and by analyzing the processes of their production, circulation, and reception, I am also making an argument about how vernacular languages like Hindi came to be refashioned as mediums of literary and intellectual discourse in second-millennium South Asia. For the past decade or so, a significant amount of scholarly attention has been given to reexamining the process of vernacularization in South Asia, that being the process through which vernacular languages like Hindi, Bengali, Gujarati, Kannada, Telugu, and Tamil (to name just a few such languages) came to occupy a place alongside the so-called cosmopolitan languages of Sanskrit, Arabic, and Persian as mediums of literary, religious, and scholastic discourse. ${ }^{3}$ The ideas of the Sanskritist Sheldon Pollock have been particularly influential in this discussion; Pollock posits that vernacular languages had first to be "literized" (i.e., committed to writing) and then "literarized" (re-formed in the image of the superposed cosmopolitan language - that is, Sanskrit-by adopting the genres, styles, and conventions of the cosmopolitan) in order to become "workly" languages— that is, languages capable of carrying intellectual and creative discourses. Pollock emphasizes that kāvya, poetry or "literature proper," was the primary arena for this shift to the vernacular, with other discursive spheres, such as that of religion, following only later. ${ }^{4}$ Other scholars, such as Christian Novetzke, Francesca Orsini, and Allison

2 I use the terms "object" and "thing" here in the sense defined by Bruno Latour, as nonhuman, perhaps non-sentient material "objects" that nevertheless have an agentive power to shape human thought and action. Bruno Latour, Reassembling the Social (New York: Oxford University Press, 2005), 63-86.

3 See, for example, the pathbreaking volume Literary Cultures in History: Reconstructions from South Asia, ed. Sheldon Pollock (New Delhi: Oxford University Press, 2003), which traces the development of literary cultures in multiple South Asian languages.

4 Sheldon Pollock, The Language of the Gods in the World of Men: Sanskrit, Culture, and Power in Premodern India (Berkeley: University of California Press, 2006), especially 298-309 and 423-36. 
Busch, have challenged or modified aspects of Pollock's thesis; two particularly contentious questions are whether religious movements may have played a larger role in driving vernacularization than Pollock acknowledges, and how much influence the establishment of an Islamicate political culture at the beginning of the second millennium in North India may have had on the trajectory of vernacularization there. ${ }^{5}$

My contribution to this discussion is characterized by the following aspects: first, I take a step back from "literature proper" to look at other genres, particularly religious scholarship, as well as other forms of nonliterary scholarship like astrology, to see if and how these discourses participated in driving the process of vernacularization. I have found that in the process of making the vernacular into a "workly" language that could carry intellectual content, composers in early Hindi actually redefined the distinctions between genres like "literature" (kāvya), "music" (gìta), and "science" (śastra). Second, I suggest that the material aspects of writing and reading played an important role in refashioning the vernacular as a medium of literary and intellectual discourse-sometimes as important a role as that of the textual content of vernacular works. If we were to say that early composers in Hindi "repackaged" the vernacular as a literary and scholastic language, then we should indeed pay attention to the language's material "packaging" - in other words, the formats, bindings, and illumination of manuscripts, as well as their paratexts, circumstances of performance, and even their storage. Finally, in order to perceive the general contours of vernacular manuscript culture, I employ techniques associated with both "close reading" and "distant reading" (to use Franco Moretti's terminology). ${ }^{6}$ In the context of this study, close reading includes the detailed examination of

5 Allison Busch, "Hindi Literary Beginnings," in South Asian Texts in History: Critical Engagements with Sheldon Pollock, ed. Whitney Cox, Yigal Bronner, and Lawrence McCrea (Ann Arbor, MI: Association for Asian Studies, 2011), 203-25; Francesca Orsini, "How to Do Multilingual Literary History? Lessons from Fifteenth- and Sixteenth-Century North India," Indian Economic and Social History Review 49, no. 2 (2012): 225-46; Christian Novetzke, The Quotidian Revolution: Vernacularization, Religion, and the Premodern Public Sphere in India (New York: Columbia University Press, 2016).

6 Franco Moretti, Graphs, Maps, Trees: Abstract Models for a Literary History (London: Verso, 2005). 
individual manuscripts and their histories; distant reading includes comparative and quantitative, as well as qualitative, analysis of large numbers of manuscripts (usually focusing on their metadata, such as date and location of copying, scribe, dimensions, format, etc.). I am increasingly finding that using these two approaches together tells us more than either of the approaches can when used on its own.

\section{Methodology and Materials}

My argument in this essay, that intellectual networks can be reconstructed using data obtained from manuscripts, and that those manuscripts themselves are the traces of material exchanges that cannot be separated from ideological ones, is based on data obtained from approximately three hundred manuscripts, all in the language of early Hindi, and dating from the late sixteenth to the late eighteenth centuries. I will occasionally make reference to manuscripts in other languages, for the sake of comparison. ${ }^{7}$ In particular, I look at a relatively large corpus of manuscripts produced by two sectarian religious traditions over a period of roughly two hundred and fifty years, analyzing their metadata in order to see patterns of production and circulation. ${ }^{8}$ To give a fuller and more detailed picture of what these pat-

7 The manuscripts used in this study are held by the following institutions: the Rajasthan Oriental Research Institute's branches at Jodhpur and Jaipur; the Rajasthani Shodh Sansthan, Jodhpur; the Abhay Jain Granthalaya, Bikaner; the Maharaja Sawai Man Singh II Museum, Jaipur; the Shri Dadu Mahavidyalaya, Jaipur; the Mahamaya Mandir, Navalgarh; the Nagari Pracharini Sabha, Banaras; the Hindi Sahitya Sammelan, Allahabad; the Vrindavan Research Institute, Vrindavan; and the University of Pennsylvania. I thank the directors and staffs of these institutions for their assistance in locating, viewing, and in some cases digitizing the manuscripts. Special thanks are due to Benjamin Flemming and John Pollack at the Kislak Center at the University of Pennsylvania for their time and help, and for their efforts to make the wealth of Indic manuscripts at the university available to scholars and the public.

8 I characterize this corpus as being "relatively large" because although tens of thousands of manuscripts in early Hindi are currently available in India (very few of which have been studied in any detail), the lack of information about the provenance of many of these manuscripts makes their attribution to a particular sectarian tradition difficult. As we will see later in the 
terns mean or point toward, I also examine the individual histories of copies of a few particular works produced by scholars from these two traditions.

The sectarian religious communities under consideration here are the Dadu Panth (lit. "The Path of Dadu”) and the Niranjani Sampraday (roughly translatable as “The Sectarian System of Those Who Worship Niranjan”). Both communities coalesced around charismatic poet-saint figures toward the end of the sixteenth century, and developed organized monastic orders and scholastic literatures beginning in the early seventeenth century. The Dadu Panth developed around the figure and poetry of Dadu Dayal (15441603), a cotton carder who preached devotion to an ineffable, all-pervasive godhead, while the Niranjani Sampraday grew up around the figure and poetry of Haridas (d. 1644?), said to have been a highway robber before being converted to the worship of a nirgun (unqualified) Absolute. The poetry, theologies, religious aesthetics, and regimens of spiritual practice articulated by the two saints are remarkably similar, and the communities of their respective followers were evidently engaged in a productive exchange of ideas and texts with one another from early on in the sects' interwoven histories. ${ }^{9}$

\footnotetext{
essay, the diligence of Dadu Panthi and Niranjani scribes in regard to noting the place, time, and institutional context of a manuscript's copying allows us to identify corpora of manuscripts produced by these monastic communities at a scale not possible for many other religious sects. 9 On the history and literature of the Dadu Panth, see Monika Horstmann, Crossing the Ocean of Existence: Braj Bhasa Religious Poetry from Rajasthan: A Reader (Wiesbaden: Harrassowitz, 1983); Horstmann, Symbiotic Antinomy: The Social Organization of a North Indian Sect (Canberra: Australian National University, 1986); Horstmann, "The Example in Dadupanthi Homiletics," in Tellings and Texts: Music, Literature and Performance in North India, ed. Francesca Orsini and Katherine Butler Schofield (Cambridge, MA: Open Book, 2015), 31-59; and James M. Hastings, "Poets, Saints and Warriors: The Dadu Panth, Religious Change and Identity Formation in Jaipur State Circa 1562-1860 CE” (PhD diss., University of Wisconsin, Madison, 2002). In Hindi, see Swami Narayandas, Śri Dādū Panth Paricay: Dādū Panth Kā Itihās (Jaipur: Sri Dadu Dayalu Mahasabha, VS 2035, 1978/9 CE). On the history of the Niranjani Sampraday, see Swami Mangaldas, ed., Śrī Mabārāj Haridāsjī Kì Vāṇ̄ (Jaipur: Nikhil Bharatiya Niranjani Mahasabha, 1962); Ratanlal Mishra, Nirañjañ Sampradāy: Sādhanā Evaì Sāhitya (Navalgarh: Mahamaya Mandir, 1998). Both of these religious communities, despite their importance in precolonial North India, have remained relatively neglected in modern scholarship in comparison with other traditions of the period.
} 
The majority of examples presented below are taken from four scholastic works composed by monks of the Dadu Panth and Niranjani Sampraday (though the broader conclusions that I outline are based on data collected from the larger corpus of manuscripts described above). The first of these is the Jũan Samudra (Ocean of Wisdom, 1653) of the Dadu Panthi monk Sundardas (1599-1689). The Jũan Samudra is a versified theological exposition that melds yogic thought and practice with Advaita Vedanta (nondualist thought deriving from late Vedic literature). The second is the Vedānta Mahāvākya Bhāșā (Commentary on the Great Pronouncements of the Vedanta, 1660) of the Niranjani monk Manohardas, a versified translationcum-commentary of the Chandogya Upanisad, a work of metaphysics (among other things). The third is the Vairägya Vrnd (Collection of Verses on Nonattachment, 1663) of the Niranjani monk Bhagvandas, a versified commentary on the Vairägya Śataka (Century of Verses on Non-attachment), an anthology of Sanskrit verses by the poet Bhartrihari (ca. sixth century CE). The fourth and final work is the Chandaratnāvali (Necklace of the Jewels of Meter, 1738) of the Niranjani monk Hariramdas, a versified treatise on prosody.

\section{Vernacular Religious Scholarship: What Was It?}

The brief description of works above gives some sense of what I mean by "vernacular religious scholarship" in this essay, but a more comprehensive definition is necessary before we proceed. A simple definition might be "works of scholarship composed in a vernacular language" (in this case, Hindi), but that would obscure the fact that, as suggested earlier, vernacular composers refashioned generic distinctions, including those of scholastic genres. Thus, scholastic genres in Hindi did not look exactly like their predecessors in Sanskrit, Prakrit, Apabhramsha, Arabic, or Persian. For example, not only the four works described above, but all of the works used in this study were composed in verse. With the exception of Indrajit's Vivekadīpika (The Lamp of Discrimination, ca. 1600) and a lost work by an early eighteenth-century Niranjani monk, we have no extant examples of vernacular scholastic literature in prose from this period in North India. (In 
contrast, Sanskrit, Persian, and Arabic contained many scholastic works composed in prose. $)^{10}$

Many early vernacular religious intellectuals composed original works of theology, metaphysics, and liturgy; the J̃̃̄n Samudra of Sundardas is one example of such scholarship. In the case of the Dadu Panth and Niranjani Sampraday, monks and saint-poets most often composed treatises on yogic practice, metaphysics (in the tradition of Advaita Vedanta mentioned above), and cosmology, in addition to non-scholastic poetry in the form of bhajans or hymns. (As we shall see later, these poets' scholastic works circulated in quite a different material form than their hymns.) As numerous as, if not more numerous than, these original works are translations of, and commentaries on, works in Sanskrit dealing with theology, philosophy, the epics (mabākārya, i.e., the Mabābhārata and Rāmāyaña), and even poetry proper (kāvya) and literary theory (kāvya śāstra). In these texts, commentary and translation are often one and the same thing, as an important purpose of "commentary" was the elucidation of the meaning (artha) of the original text. The Vedānta Mabāvākya Bbāșā of the Niranjani Manohardas and the Vairāgya Vrnd of Bhagvandas are examples of this type of scholarship. These translations-cum-commentaries made knowledge from Sanskrit texts available not only to "courtly" or elite audiences that, by the early modern period, were less and less conversant in Sanskrit, but also to non-elite audiences who did not have a history of prior engagement with the Sanskrit intellectual and literary sphere; in the case of the Dadu Panth and Niranjani Sampraday in northwestern India, I believe this second group of readers consisted primarily of merchants (though individuals from other castes and communities also produced and consumed such works). Finally, some vernacular intellectuals attempted to bring aspects of literary and aesthetic theory into the sphere of religious thought, composing original treatises on poetic and aesthetic questions, but from a distinctly religious point of view. The Chandaratnāvali of Hariramdas is one such work, presenting itself as a treatise on

10 Scholastic works of prose in the vernacular do begin to appear in the late eighteenth century; for example, the Paramānand Prabodh (1761?) of Anandram, a commentary on the Bhagavadgita, and the Pārasbhāg of Bhai Addan, a translation of the Kimiyā-yì Sa'ädat of Al-Ghazali, among other works. 
prosody intended for religious poets, and insisting on the importance of correct poetic form to the realization of a work's intended spiritual affect and effect.

These original works combined formerly distinct areas of knowledge like yoga and Advaita Vedanta, prosody and hymnology, and elements from formerly distinct genres like dharma-śāstra (treatises on right conduct); bhāsya, țīka and vrtti (various types of commentary); and kāvya-śāstra, among others. This is how such vernacular works helped to redraw distinctions between genres and arenas of discourse like the religious, the literary, and the philosophical. At the same time, the composers of these works imagined themselves to be operating firmly within the ambit of śastra, the discursive mode often translated as "treatise" that involves a distinctly scientific approach to its subject matter, be that subject matter religion, literature, music, biology, gemology, and so on. Consequently, these works "produced" the vernacular intellectuals that produced them, in the sense that composing a work of the scholarship in the vernacular (in particular a commentary on, or translation of, a Sanskrit text) established an individual's command over Sanskrit and its knowledge systems as well as his ability to compose in the vernacular-especially since, as noted above, commentaries and translations were always composed in rhymed verse. These works also helped to produce vernacular scholars in the sense that they were used as pedagogical materials, and thus through circulation, manuscripts of these works produced networks of scholars connected by theology and by exegetical tradition. These networks extended across both space (the geographical region) and time (the generations of teachers and disciples enumerated in the colophons that I describe below).

\section{Manuscript Cultures on the Eve of Vernacularization}

When literary and scholastic works in Hindi began to be composed and written down in the fourteenth through sixteenth centuries, what did the manuscript culture of North India look like? What types of textual artifacts were in circulation that could have served as models for the pioneers of vernacular manuscript culture? There was, in fact, a dizzying array of inscribed 
objects in numerous languages and using many different kinds of materials, so I will mention only the most ubiquitous types here, since they appear to have had the greatest influence on the development of vernacular manuscript culture and are most pertinent to the question of scholastic literature. ${ }^{11}$

The first of these was a manuscript most often referred to in Hindi sources as pothī (Sanskrit pustaka > Prakrit puttha > Hindi pothī). Its wide, thin dimensions and orientation derive from the palm leaves on which such manuscripts were inscribed; this was one of the most common types of manuscript (along with birch bark) used in pre-Sultanate South Asia for Sanskrit, Prakrit, and Apabhramsha, as well as for Dravidian languages. ${ }^{12}$ After the establishment of Sultanate rule in the northern part of the subcontinent at the turn of the thirteenth century, palm leaf was slowly replaced by paper in the north; however, these new paper manuscripts retained the dimensions, orientation, and decorative elements of their palm leaf archetypes, to the extent that scribes and illustrators even placed decorative "holes" in the middle of folios, where strings would have passed through the palm leaf to "bind" them (fig. 1). ${ }^{13}$ Pothis were always made of loose

11 For a general overview of manuscripts during this period, one may consult Jeremiah Losty, The Art of the Book in India (London: British Library, 1982), and B. N. Goswamy, ed., The Word Is Sacred, Sacred Is the Word: The Indian Manuscript Tradition (New Delhi: Niyogi Books, 2006); however, as works of art history, these studies tend to focus on outstanding examples of the book arts rather than on the general contours of manuscript culture itself. The study of manuscript culture during this period and its relationship to the various languages, genres, and performance practices of the time has yet to be undertaken. Francesca Orsini has provided some valuable suggestions for how one might begin such an undertaking (at least from the point of view of literary history) in "How to Do Multilingual Literary History?"

12 The two most common types of leaves were those of the toddy palm (Borassus flabelifer) and the talipot palm (Corypha umbraculifera), but the leaves of other species of trees were also used. Differences in tree species, and the relative abundance and size of different species in different geographical regions, led to a variety of "sizes" and "formats" among these manuscripts.

13 There is no evidence that the shift from palm leaf to paper occurred immediately, or steadily, after the introduction of paper manuscripts during the Sultanate period (which lasted from roughly the late twelfth to the early sixteenth centuries). The causes or catalysts of the shift have yet to be identified by historians, partly because so little is known about paper production during the Sultanate period or, for that matter, about manuscript culture in general during this time. It is worth noting that, despite the overwhelming hegemony of paper during the sixteenth through nineteenth centuries, palm leaf continued to be used by some communi- 
แर्दण แनम:

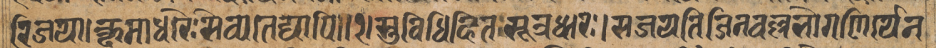

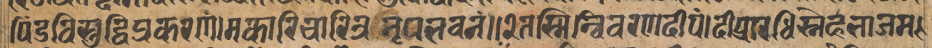

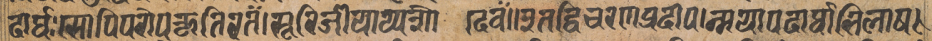

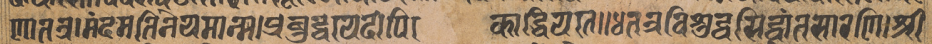

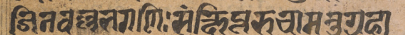

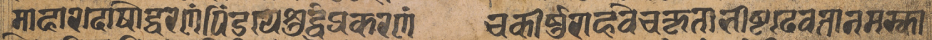

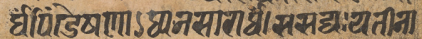

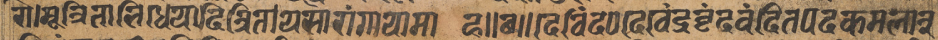

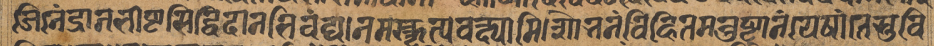
दिता सा \&

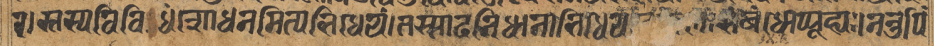

FIGURE 1. Philadelphia, University of Pennsylvania, Indic MS 10, folio $1 \mathrm{~A}$.

Pindaviśuddhivrtti (Purification of the Body), a Jain work in Sanskrit; copy dated 1569 CE. Note the decorative space left in the center of the folio where a thread would have passed through a palm-leaf manuscript.

folios; for storage these could be placed between two boards and tied with string or, more commonly in the early modern period, tied in a red cloth called a bastā (Persian, lit. "closed”). Compositions in Sanskrit, Prakrit, and Apabhramsha continued to be copied on such manuscripts throughout the period under consideration here (and, in fact, into the first quarter of the twentieth century), with Jain monks and intellectuals producing and preserving what is perhaps the greatest number of such manuscripts in the northwestern corner of the subcontinent.

The second major type of manuscript is referred to in early Hindi sources as kitāb (Arabic; not to be confused with al-kitāb, the Quran). This was a bound codex, most often (though not always) tall and thin-that is, "portrait"-in orientation. Common bindings included leather, wood, and cardboard, and its folios-usually made from paper, but occasionally parchment-were sometimes used as canvases for elaborate programs of illumi-

ties in the north. (Meanwhile, in the south, the abundance and low cost of palm leaf meant that it continued to be used into the twentieth century.) On the history of paper making in South Asia, see S. A. K. Ghori and A. Rahman, "Paper Technology in Medieval India," Indian Journal of History of Science 1, no. 2 (1966): 133-49, and Sita Ramaseshan, "The History of Paper in India Upto [sic] 1948," Indian Journal of History of Science 24, no. 2 (1989): 103-21. 


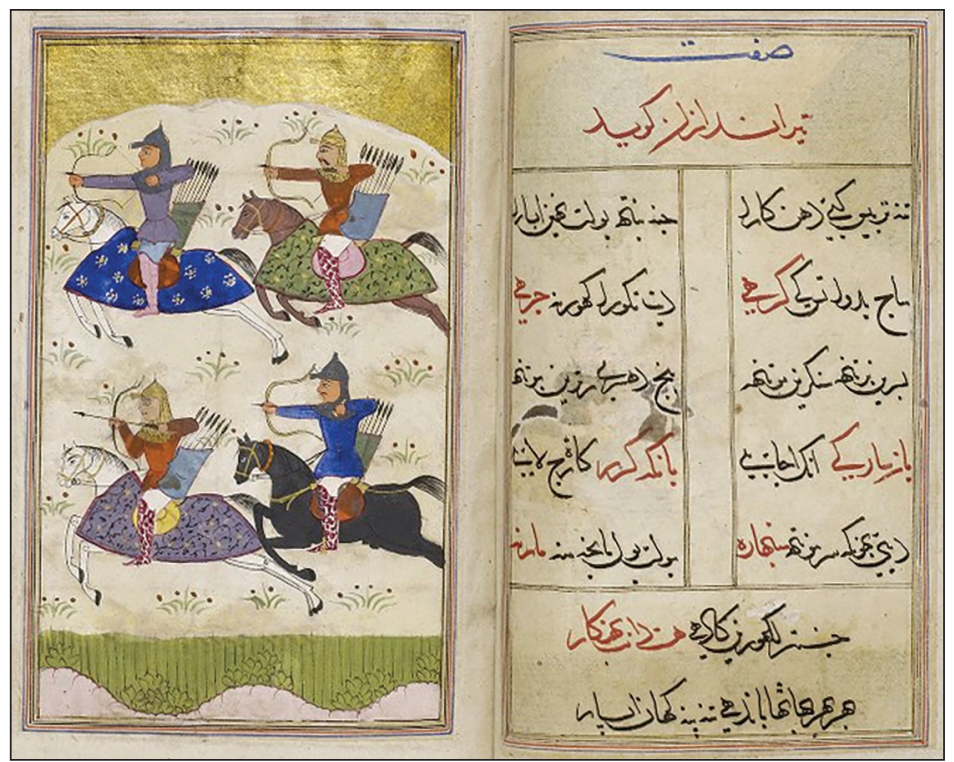

FIGURE 2. Manchester, John Rylands Library, Hindustani MS 1.

Candāyan, fols. 81B and 82A. An Islamic Sufi romance composed in 1379

$\mathrm{CE}$ and recognized by many to be the first work of Hindi literature.

Manuscript copied ca. 1570 CE.

nation and illustration. ${ }^{14}$ This was the archetypical manuscript of the Islamicate (and more specifically Persianate) literary and scholastic culture that became part of the North Indian landscape after the establishment of the Sultanates: in addition to being the vehicle for Persian and Arabic texts, the kitāb became the primary written manifestation of Persianized genres in the Indian vernaculars as well, such as the prem-äkbyān romance genre in early Hindi (fig. 2). ${ }^{15}$ Closely related to the kitäb is the safinab (Arabic via

14 There is a relative scarcity of scholarship on book culture in the North Indian sultanates, with the few existing studies being carried out by art historians. See Élö̈se Brac de la Perrière, L'art du livre dans l'Inde des sultanats (Paris: PUPS, 2008).

15 For an overview of this genre, see Aditya Behl, Love's Subtle Magic: An Indian Islamic Literary Tradition, 1379-1545 (New York: Oxford University Press, 2012). Although manuscripts of such Sufi romances are also found copied in the Devanagari script and in the poth $\bar{\imath}$ format (including MS Indic 28 in the University of Pennsylvania collection), the earliest and greatest number of copies are found in the codex format and copied in the Perso-Arabic script. 
Persian, lit. "boat"), a (usually) bound notebook of long proportions in which students, connoisseurs, and aspiring poets in Persianate literary and scholastic culture would copy verses of poetry, anecdotes about poets, and other literary information (akin to the "writing tables" or "commonplace book" of early modern Europe); these were used by an individual and not intended for circulation. ${ }^{16}$

The third and final type of textual artifact that predominated during this period was also a type of codex, and it also includes text artifacts that would most accurately be described as notebooks. Called a guțā (Sanskrit guțika, lit. "lump" or "ball") in vernacular sources, this codex, bound on the vertical side in a cardboard or cloth cover, often served as a notebook for poetry, song, hagiographies, travelogues, financial records, yogic spells, astrological data, and really any information for which the user needed a written record (fig. 3). These tended to be used by only one individual as an aide-memoire and were not intended for circulation; however, an individual could inherit a gutka and have folios added to it. Since the paper folios were folded over each other before being bound with string, these notebooks often developed a rounded appearance (enhanced by subsequent additions of folios), and this round shape is most likely what earned them their name, gutkā. It should be noted that the term gutka designated more of a physical format than a type of content, and so it was also sometimes applied to single, bound works that were intended for circulation; however, for the sake of clarity in the context of this essay, those works that I refer to as gutkea are only those of the personal notebook type.

Even more interesting, a significant number of copies in Devanagari conform to the codex format and impagination practices of their Perso-Arabic predecessors.

16 It should be noted that the term safinah was also sometimes used for very deliberately crafted collections of calligraphy. For example, the folio of calligraphy by (Mir) 'Imad alHasani al-Katib (d. 1615) found in MS 1-85-154.77 at the U.S. Library of Congress is from such a safinah. An individual's safinah containing information about poets and verses of their poetry could often become the textual foundation for a tazkirab (Persian, "memorandum"), a poetic anthology that was indeed intended for circulation. The relationship between such personal safinah (or bayāz) and the "published" tazkirab in South Asia has been remarked upon but not studied; see Frances Pritchett, Nets of Awareness: Urdu Poetry and Its Critics (Berkeley: University of California Press, 1994), 64. 


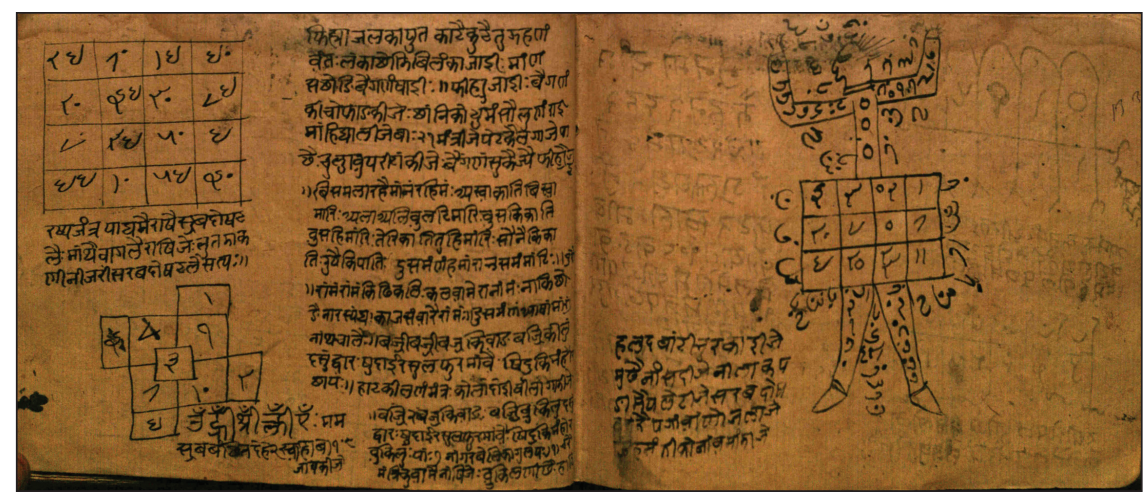

FIGURE 3. Jodhpur, Rajasthan Oriental Research Institute, MS 26334. Folios unnumbered. Copied 1687-96 CE. Pictured folios include Indic and Islamicate magic squares, incantations, and a recipe for eggplant that confers yogic powers. Manuscript consists primarily of religious hymns and poetry.

These three major types of manuscripts, in addition to many other types of inscribed objects, circulated in the multilingual world of North India at the beginning of the rise of vernacular textual culture in the region (the fourteenth through sixteenth centuries). The pioneers of vernacular literary and scholastic culture thus had a variety of models from which to draw ideas and inspiration when they began to commit their compositions to writing. It is therefore significant that monks like those of the Dadu Panth and Niranjani Sampraday, as we will see in the following sections, chose to inscribe their scholastic works (which they imagined to be taking part in the discourse of śastra) in the pothi format, as opposed to the kitāb or gutka format. That the monks of these communities did employ manuscripts of the kitāb and guțka types for texts of other genres and for purposes other than study (e.g., liturgy, communal singing) suggests that there existed a connection between the material form of a manuscript and the type of text inscribed within it. It is on this basis that we can speak of a "vernacular manuscript culture," as opposed to the manuscript cultures of those linguistic and literary systems from which it drew and in relation to which it positioned itself, such as Sanskrit, Persian, and Arabic. 


\section{A Scholarly Pothī}

What distinguished the manuscript of a scholastic work from other types of text artifacts in the vernacular manuscript culture of this period? Some of the elements particular to scholarly "books" have been hiding in plain sight but have passed largely unremarked upon in scholarship on vernacular literary culture, while other elements are less obvious. In this section, I will briefly identify the salient features of vernacular scholastic manuscripts, that is to say manuscripts that contained scholastic works in the vernacular and, importantly, that were intended for use or performance in the social and institutional contexts of scholarship and pedagogy.

The first thing that one notices when surveying works of vernacular scholarship in Hindi from the sixteenth, seventeenth, and eighteenth centuries is that they are found overwhelmingly (though not exclusively) in the pothī format described above: the manuscripts consist of wide, thin, unbound folios inscribed on both sides and "bound" in a cloth bast $\bar{a} .{ }^{17}$ The folios are always made of paper; by this time, paper-making industries had been established at various urban centers across the north, and cloth-made paper was readily available. Rajasthan, the region where the Dadu Panth and Niranjani Sampraday were active, had its own centers of paper production, and was ringed by several more such centers. ${ }^{18}$ Folio dimensions varied widely, but the size and marking of margins (with one or two lines in red ink) appear to have been remarkably regular. ${ }^{19}$ The number of lines per folio

17 Relatively few vernacular manuscripts from this period are bound with string, or between wooden or cardboard boards. It is possible that some of the manuscripts now found in bastās were originally tied with string or between boards, but none of the manuscripts that I consulted for this study showed signs of wear that would suggest the use of either string or boards. It should be noted that bastās too were changed over time, most likely due to wear; multiple manuscripts of the pothī type were often stored in one bastā. Bastās were almost invariably red in color, with one explanation being that this color repels insects.

18 Ghori and Rahman, Paper Technology in Medieval India, 137-42. The major paper-making centers in Rajasthan were Sanganer (near Jaipur), Kota, and Tijara (in Alwar). The majority of paper produced at these centers was made of cloth rags.

19 Ascertaining just how regular the measuring and marking of margins were will require a quantitative study of a larger data set than that which I utilize in this paper. I have begun collecting data for such an analysis using manuscript catalogs from Indian libraries, which 
and characters per line also varied widely based on the size of the scribe's hand, but at monasteries or other institutions where string guides or wooden embossing boards were used for ruling folios, these elements are uniform, providing us with clues as to which manuscripts may have been copied at the same location. Black ink was used for body text, and red ink was used for rubrics and other paratextual elements (sometimes, instead of red ink, scribes highlighted rubrics with red powder, often made of vermillion or bingul).

These paratexts are an important but almost entirely overlooked element of early vernacular literature in North India. Such paratexts included opening invocations (sacred syllables, titles of works, mañgalācaraña verses intended to ward off danger and give compositions an auspicious beginning), section headings, the marking of direct and indirect quotations (e.g., rāma uvāca, "Ram said . .."), verse numbers, poetic meters, rāgas (melodic structures), and colophons. In contrast to the body text of these early vernacular works, the paratexts were almost invariably in Sanskrit (or sometimes in a language that can most accurately be described as a vernacularized, pidgin Sanskrit, in which Sanskrit lexicon and morphology are mixed with vernacular morphology, grammar, and syntax). These elements often appear to have been added after the composition of the work by scribes, compilers, or scholars.

Why would scribes and scholars, like the Dadu Panthi and Niranjani monks that we will examine shortly, add such paratexts to existing works, and in Sanskrit or pseudo-Sanskrit, especially when their intellectual project, as it were, was to produce and make available knowledge in the vernacular? I believe that inserting or appending such elements was part of the process through which vernacular intellectuals re-formed, re-presented, and edited vernacular texts into "proper" literary texts (kāvya) or works of "serious" scholarship (śāstra). If, as Pollock argues, the vernacular had to

often note details of folio size, lines per folio, etc. Goran Proot's article, “Converging Design Paradigms: Long-Term Evolutions in the Layout of Title Pages of Latin and Vernacular Editions Published in the Southern Netherlands, 1541-1660," Papers of the Bibliographical Society of America 108, no. 3 (2014): 269-305, has been particularly helpful in conceiving of such a study. 
assimilate the generic and discursive forms and conventions of the cosmopolitan (i.e., Sanskrit) in order to become a vehicle of discourse, then it seems reasonable that its material, written representation should also need to assimilate the conventions of the cosmopolitan's written textual culture in order to re-present the textual content as "literary," "scholastic," and so on. For example, the oldest manuscripts containing hymns by the saint Kabir (fl. sixteenth century?), which were copied in the late sixteenth and early seventeenth centuries in (mostly) bound, anthological hymnals, present his compositions as individual lyrics, and if they include any paratext, it is only the name of the rāga in which the lyric is to be sung. ${ }^{20}$ In contrast, later manuscripts (dating from the late seventeenth and eighteenth centuries, and conforming to the potb $\bar{\imath}$ format) do something remarkably different: they present many of the same lyrics, but organize them thematically and provide introductory and closing passages in (pseudo-) Sanskrit that reframe the lyrics as a unified theological treatise. ${ }^{21}$ Such "repackaging" is found in manuscripts produced by monks of the Dadu Panth and Niranjani Sampraday, making these religious communities important agents in the re-inscription of vernacular song (git $t a$, a genre excluded from the realm of literature in Sanskrit textual culture) into vernacular scholarship. ${ }^{22}$

20 These early manuscripts include the so-called Fatehpur manuscript and Goindval Pothis, as well as the sarvāingi ("comprehensive") collections of the Dadu Panth, although the latter also group some of their material thematically. See Pada Sūradāsaj̄ Kā / The Padas of Surdas, ed. Gopalnarayan Bahura and Kenneth Bryant (Jaipur: Maharaja Sawai Man Singh II Museum, 1984); The Goindval Pothis: The Earliest Extant Source of the Sikh Canon, ed. Gurinder Singh Mann (Cambridge, MA: Department of Sanskrit and Indian Studies, Harvard University, 1996); Sarvāngì of Gopaldas: A 17th Century Anthology of Bhakti Literature, ed. Winand Callewaert (New Delhi: Manohar, 1993); The Sarvangi of the Dadupanthi Rajab, ed. Winand Callewaert (Leuven: Departement Oriëntalistiek, 1978).

21 Thus we find manuscripts of Kabir's poetry bearing titles like Jog Granth ("Treatise on Yoga") and Granth Battisī ("Treatise of Thirty-Two Verses"), titles that are subsequently used by scribes to group together lyrics by other saint-poets such as Dadu Dayal and Haridas Niranjani. I have explored this phenomenon in Bhakti Kāvya Meṁ Nirgun-Sagun Vibbājan Kā Aitibāsik Adbyayan / An Historical Study of the Nirgun-Sagun Distinction in Bhakti Poetry, MPhil thesis, Jawaharlal Nehru University, 2007, 44-61.

22 The relative chronology here-in which early vernacular manuscripts appear thin in terms of Sanskrit paratexts and later manuscripts appear to use them more extensively-raises a question regarding Pollock's theory of vernacularization. If literization of the vernacular 
As I suggested briefly above, the multilinguistic character of North Indian literary culture and the variety of textual artifacts that were in circulation at the time when the pioneers of Hindi were beginning to transform this vernacular into a literary language provided a variegated field of models and possibilities. This complicates Pollock's model of vernacularization, in which the vernacular recasts itself largely in the mold of a single cosmopolitan (e.g., French emulating Latin, Kannada emulating Sanskrit, Urdu emulating Persian). ${ }^{23}$ Here, the multipolar discursive and material dimensions of textuality make for a richer and more complicated process of appropriation, assimilation, and innovation. This complexity is reflected in the paratexts of the scholastic works under consideration here: although ostensibly adopted from Sanskrit textual culture, neither their language (a "vernacularized" form of Sanskrit) nor their content exactly resembles that found in Sanskrit textual culture. For example, the frequent use of terms like atha ("now [begins]"), iti samāptam ("thus ends"), likhyatam/likbitam/ likbyam ("[it] is written”), tathā dobā ("thus a couplet”), praśna ("a question"), and uttara ("an answer") does not parallel their use in Sanskrit śāstra (or in any other genre, for that matter).

occurred through the adoption of Sanskrit conventions, then why do we see this more in later manuscripts, when the vernacular had become somewhat established as a literary and scholastic medium, and less in earlier manuscripts, when (one assumes) the pioneers of the vernacular would have been harder pressed to demonstrate the vernacular's literary and scholastic character? At present, it appears to me that the early manuscripts (being as they are primarily song books) reflect less of a concern with scholastic self-fashioning, and that the later manuscripts reflect an increasing self-consciousness of the communities' scholastic identity. This argument can only be made for the anthologies of the Dadu Panth and Niranjani Sampraday; other communities like the Sikh tradition appear to have followed a different trajectory, thus further complicating Pollock's model.

23 Here I do not mean to oversimplify Pollock's theory, which simultaneously recognizes in the vernacular something "new" and "fresh" that is rooted in "place," and something that reaches back to the model provided by the cosmopolitan (and therefore place-less) theorization of the Sanskrit literary system (Language of the Gods, 283-91). Pollock of course recognizes the emergence of new genres and literary and rhetorical forms particular to the vernacular, but these are still theorized (by both pre-modern Indian commentators as well as by Pollock) in relation to the single and singular archetype of Sanskrit. 
Furthermore, at the risk of repetition, I want to emphasize that the dynamics of vernacularization in a multilinguistic literary and scholastic environment are also reflected in the very choice of the potbi , over other forms, as the material vehicle for the scholastic thought of Hindu religious communities like the Dadu Panth and Niranjani Sampraday. The monks of these religious orders-like their peers in other so-called bbakti ("devotion") sects of the time, such as the Pusthimarg, Kabir Panth, Ramanandi Sampraday, and Ram Snehi Sampraday-inscribed their scholastic works into the type of manuscript that typically held works of sáastra in Sanskrit, again reflecting their understanding that they were participating in a tradition of śastra. These same monks inscribed other types of texts-most often hymns, but also hagiographies, mabātmyas (works extolling and explaining the purpose of a particular festival, ritual, or text), and works used for teaching in the context of communal worship among lay devotees (as opposed to study among educated monks) - into codices of the kitāb and guțkà types, and in doing so they appear to have been emulating the use of the Qur'an as a symbolic focal point and ritual implement in communal worship in the Islamic traditions of the region. ${ }^{24}$ These distinctions reflect a pronounced if rough correspondence between genre, performance context, and the material form of the "book" in early vernacular manuscript culture, a situation that arose precisely because of the possibilities offered by the multilingual literary environment of the time and its correspondingly multifarious manuscript culture. The multireligious context of early modern North India also clearly contributed to this diversity of manuscript forms (as the aforementioned example of the Qur'an should make clear), but I want to emphasize that religious difference does not appear to have been a primary factor or

24 Gurinder Singh Mann has noted that ritual practices around the Qur'an likely influenced the development of the Sikh scripture, the Guru Granth Säbib, into the focal point of the Sikh ritual and theological imagination. Mann is careful to point out that it was the use of the material object of the Qur'an in pedagogical and liturgical contexts and its presence in the physical space of a mosque, not necessarily its textual content, around which Muslim practices took shape. Gurinder Singh Mann, The Making of Sikb Scripture (New York: Oxford University Press, 2001), 12. I have argued that a similar influence was at work on the Dadu Panth and Niranjani Sampraday. Tyler Williams, Sacred Sounds and Sacred Books (PhD diss., Columbia University, 2014), 279-341. 
driver of this diversity. Hindu religious sects like the Dadu Panth and Niranjani Sampraday do not appear to have adopted manuscript forms based on any straightforwardly communal association with Hindu or Muslim traditions; rather, they utilized all of these forms, in different contexts, based on associations of textual genre and performance practices. Thus, hymns of Dadu Panthi and Niranjani poets appear most frequently in gutkās (and less frequently in potbīs), while the scholastic works of Dadu Panthi and Niranjani poets appear most frequently in pothīs and almost never in gutkās.

\section{Producing Manuscripts of Scholarly Works}

Who produced these manuscripts, and where and how did they produce them? In the case of the Dadu Panth and Niranjani Sampraday, scholastic manuscripts (and most other manuscripts of sectarian works) were copied by initiated (celibate and non-celibate) monks or sādhus working at monasteries (maths) and at non-monastic religious centers simply called dhāms ("abodes"), where both communal worship by lay devotees and more solitary worship by monks would take place. ${ }^{25}$ We know that these texts were copied at such locations because the copyists were often diligent about noting the location of copying in the manuscripts' colophons (fig. 4). Using this geospatial metadata, so to speak, we can actually track the relative volume of manuscript production at different monastic centers (fig. 5). The data that I have been able to collect and process so far suggests a correlation between the volume of manuscript production and the presence of a significant

25 Part of the disruptive nature of these vernacular religious movements in the region under consideration here (often referred to as bhakti movements, bhakti being roughly translatable as a kind of shared devotion) was that they were not centered around temple worship, the traditional physical and institutional locus of the upper caste priesthood and monastic culture. Instead, they initially occupied the physical space of markets and other public areas, as well as the courtyards of private residences. When they did establish their own physical "places," these were characterized by open, multiuse spaces for congregation (without the focal point of an image or garbha-grhba, i.e., central sanctum housing a deity). They also built maths or monasteries, which often served as locations for communal worship by lay devotees as much as they provided a space for quiet contemplation by monks. 


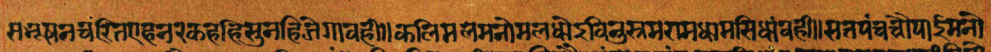

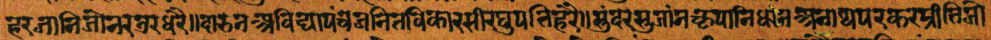

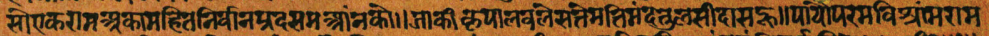

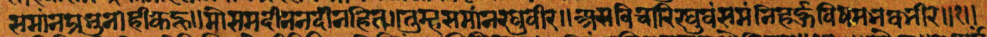

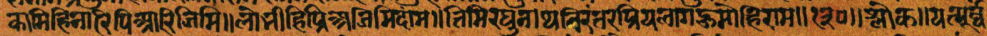

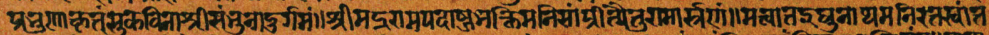

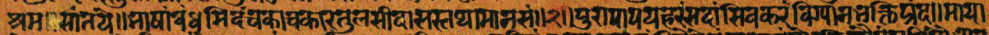

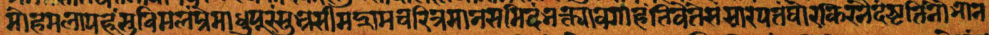

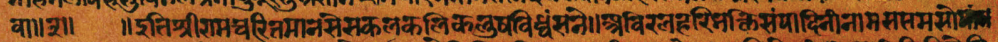

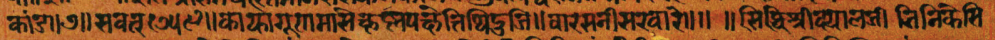

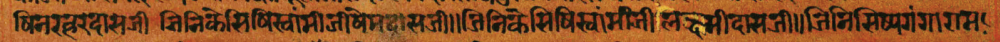

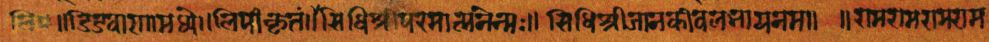
तृक्षरदासपगनार्था।

FIGURE 4. Jodhpur, Rajasthan Oriental Research Institute, MS 27518, fol. 32A. The Rāmcaritmānas of Tulsidas. Copied 1704. The colophon reads: "Saturday, the second day of the dark half of the month of Phalgun, 1759 [5 March 1704]. Copied by Gangaram, disciple of Swami Lakshmidas, disciple of Swami Khemdas, disciple of Narhardas, disciple of the Great, Fully-Realized Dayal Ji [Haridas Niranjani], in [the city of] Didvana, for reading by Bhudhardas. Obeisance to the Great, Fully-Realized Supreme Soul. Obeisance to the Great, Fully-Realized Beloved of the Daughter of Janaka [i.e., Rama]. Ram Ram Ram Ram.”

population of lay devotees hailing from merchant castes at a given location; that is, more manuscripts were produced by Dadu Panthi and Niranjani monks at cities that were major trade centers and that were home to large merchant communities, suggesting a connection between mercantile literacy and either the production, consumption, or circulation of written texts.

We also know a relatively fair amount about the identities of these monk copyists because they included information about themselves and about their monastic lineage in their colophons (fig. 4). Why would a copyist include his own name, as well as the name of his guru, his guru's guru, and so on? I believe that these colophons play an important role in certifying the quality with which a text was transmitted and "edited." In the pedagogical and scholastic world of early modern North India, texts were never intended to be read or accessed without the mediation of a qualified (adbikrta) teacher: the written text was understood to be a prosthetic of memory, and the locus of the actual or "true" text was understood to be the mind of the teacher. ${ }^{26}$

26 This understanding is vividly reflected in a vignette shared by the Sufi saint Nizamuddin Auliya with his disciples: when Nizamuddin's spiritual master, Sheikh Fariduddin, finds that 


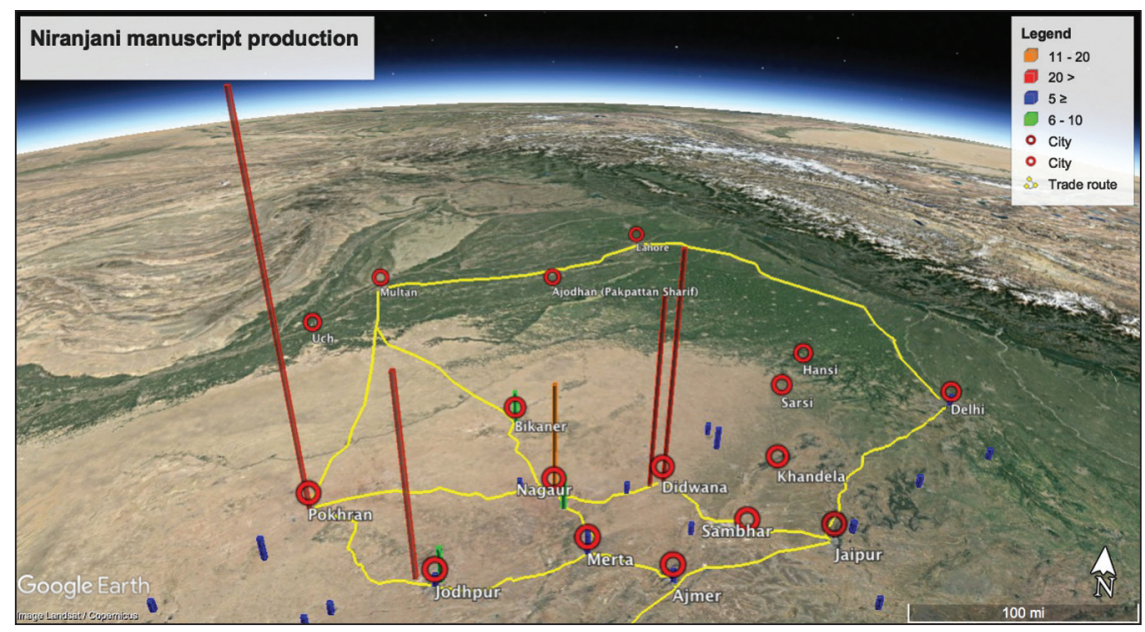

FIGURE 5. Production of manuscripts by Niranjani monks, 1680-1800. Production was higher in cities with significant trade and merchant populations. Map produced using Google spreadsheets and Google Earth. (C) 2015 Google Inc., used with permission. Google and the Google logo are registered trademarks of Google Inc.

Therefore, when copyists wrote down their guru-disciple lineage at the end of the manuscript, they performed their intellectual pedigree and attested to the quality of the intellectual and institutional context in which the copied text had been transmitted.

\section{Circulation of Vernacular Scholastic Texts}

We can draw some tentative conclusions about the circulation and reception of these scholastic texts by looking at their colophons and at the collections in which the manuscripts are found, as well as by examining notations,

a manuscript from which he is teaching contains numerous errors, the young Nizamuddin offers to fetch the Sheikh a better copy. The offended master asks his pupil, "Has the dervish no power to correct a defective manuscript?" Morals for the Heart: Conversations of Shaykb Nizam Ad-Din Awliya Recorded by Amir Hasan Sijzi, ed. and trans. Bruce Lawrence (New York: Paulist Press, 1992), 109. 
seals, and other information appended to them after their creation. ${ }^{27}$ In some colophons, the scribe clearly states that he has copied the text for his own guru. This is phrased as pathanārtha, a calque from Sanskrit meaning "so that $(\mathrm{X})$ may read $(\mathrm{Y})$. . . ." For example, the frequently encountered phrase guru pathanārtha likbitam can be translated as "[the text] was copied for the purpose of the guru's reading." The term pathana, however, also has other meanings, including "to study" or "to recite" from a written (or even unwritten) text. Therefore, in cases in which the scribe has copied a text for his teacher, it should not be assumed that the text has been copied so that the teacher may "read it" in the sense of encountering it for the first time; rather, it is more likely that the scribe has made the copy so that the teacher may teach from it, or use it as a reference, an aide memoire. This is consistent with the scholastic and pedagogical culture of sects like the Dadu Panth and Niranjani Sampraday, in which qualified religious preceptors were understood to be the repositories and arbiters of the authentic text. The manuscript is thus a marker of a certain type of exchange between master and disciple: the scribal labor of the disciple is exchanged for the (continuing) pedagogical labor of the guru (and, of course, his spiritual blessings). The disciple copies the text, a form of material (even mechanical) labor, so that the guru may mediate the text to him, a form of intellectual labor.

We do, on occasion, find among the manuscripts of the Dadu Panth and Niranjani Sampraday (as well as other religious groups of the time) manuscripts copied by a monk for a lay devotee. For example, the colophon of MS 26094 of the Rajasthan Oriental Research Institute, Jodhpur, a copy of the Viṣnusabasranam of Hariramdas of the Niranjani Sampraday, reports that the manuscript was "copied on Monday of the 7th day of the bright fortnight of Phalgun, 1919 (25th of February, 1863) by the devotee of Vishnu,

27 We must be careful when determining the significance of where manuscripts are found in the modern period: many manuscripts passed through multiple hands and collections before arriving at their current homes, and large-scale manuscript surveys carried out by libraries, museums, and literary institutions in the colonial and postcolonial periods have resulted in the relocation of large numbers of manuscripts. Nevertheless, when adequate information is available about the provenance of a manuscript and the history of the collection in which it is found, we can draw some fascinating inferences. 
Dularam, for reading by the devotee of Vishnu, Manganiram. Copied in the village of Muḍaā." Here, the term vaiṣnav (devotee of Vishnu) marks a shared sectarian affiliation. ${ }^{28}$ Wealthy lay devotees, in particular merchants, not only provided critical financial and logistical support to the monastic leadership of religious communities like the Dadu Panth and Niranjani Sampraday but also took an active interest in the production of religious and scholastic literature, sometimes composing works themselves. ${ }^{29}$ In this context, manuscripts like MS 26094 mark an exchange of scribal labor, on the part of the monk, for the financial and/or logistical support of the lay devotee. In the case of copies of scholastic works by monks of the community, it could be argued that this was also an exchange of knowledge for material patronage.

Some monks also used their scribal skills for commercial purposes, copying texts in exchange for money. This is a very familiar type of exchange, the exchange of labor for currency, that was common during this period. Such scribes often copied texts from multiple languages, as the process of copying was largely mechanical in nature and did not necessarily require an understanding of the meaning of a text. Manuscripts that appear to have been copied by Dadu Panthi and Niranjani monks for non-devotee clients are occasionally found, and interestingly, they include texts by authors and traditions other than those of the sects themselves, again suggesting that the

28 The term vaisnav is, of course, a much broader appellation for any devotee of Vishnu or his avatars (such as Ram and Krishna), as well as an adjective used for anything related to the worship of Vishnu and his avatars. Yet in the context of early modern Rajasthan, the use of this term in manuscripts and inscriptions tends to occur in the context of shared sectarian affiliation (and is emphasized, as in this case, by the repeated use of the term for both members of an exchange). Those familiar with the religious history of this region will likely find the use of the term for members of sects like the Dadu Panth and Niranjani Sampraday strange since both of these sects are known to have rejected the worship of anthropomorphic deities. In fact, both of these groups were significantly vaișnav in their religious aesthetic and rituals, a complexity that cannot be addressed in detail here but which deserves greater scholarly attention.

29 On merchants and the bhakti religious communities of northwestern India, see Tyler Williams, "The Ties that Bind: Individual, Family, and Community in Northwestern Bhakti," in Bhakti and Power: Debating India's Religion of the Heart, ed. John Stratton Hawley, Christian Lee Novetzke, and Swapna Sharma (Seattle: University of Washington Press, forthcoming 2019). 
text was copied as a commercial service rather than as any type of religiously connected labor. ${ }^{30}$

Some manuscripts of scholastic texts, especially works on Advaita Vedanta and yoga (like the Jñann Samudra of Sundardas and the Vedānta Mabāvākya $B h \bar{a} s \underline{a}$ of Manohardas), commentaries on the Hindu scripture of the Bhāgavata Purāna and on works of Sanskrit kāvya (like the Vairāgya Vrnd of Bhagvandas), and also a few sectarian works on poetics (like the Chandaratnāvali of Hariramdas) appear to have circulated far beyond the scribe's sectarian community. ${ }^{31}$ (Some of these manuscripts include mention of the intended "reader" in the colophon; many do not.) In the case of the Dadu Panth and Niranjani Sampraday, the two sects appear to have carried on their most robust intellectual and textual exchanges with each other: the greatest number of manuscripts produced by Niranjani monks but found in other sectarian collections are found in the manuscript libraries of the Dadu Panth, and vice versa. This would seem to make sense, as these two religious orders were highly similar in terms of theology, ritual, and religious and literary aesthetics and were often in competition for patronage and for monastic initiates from the same merchant communities. ${ }^{32}$

Manuscripts of these same texts also ended up at royal courts in the region, in particular the Rajput courts at Jaipur, Jodhpur, and Nagaur. For example, a Niranjani monk copied a manuscript of the Vairāgya Vrnd of Bhagvandas for the court of King Jai Singh II at Jaipur in 1737; 33 in 1778 the Niranjani monk Mangaldas copied a collection of works on Advaita Vedanta

30 On the other hand, we also find manuscripts of Dadu Panthi and Niranjani works copied completely "outside" the sectarian context, i.e., by scribes without clear sectarian affiliation, and for patrons without any clear sectarian affiliation. This seems to be the case, for example, with the manuscript of Hariramdas's Chandaratnāvali in the Shri Saraswati Pustakalaya library in Fatehpur, the colophon of which reads "Copied on Wednesday of the bright half of the month of Margasir, Samvat 1851 [either 26 November or 3 December 1794], for reading by the Brahmin Rambaksh.”

31 Even some manuscripts that do mention the intended user in the colophon ended up in other sectarian collections, raising fascinating questions about what types of intellectual and material exchanges occurred between monks of different sects such that these manuscripts moved from one sect to another.

32 Williams, "The Ties that Bind."

33 MS 2440.28, Maharaja Sawai Singh II Museum, Jaipur. 
for the Rathore king Vijay Singh's sons Sher Singh and Guman Singh at Nagaur; and Manohardas's Vedānta Mahāvākya Bhāṣā and Gyān Mañjarī were copied for the Kacchwaha court at Jaipur in 1722 and 1748, respectively. (A copy of Manohardas's Șațpraśni Nirnaya Bhāṣā, a work of metaphysics in the tradition of Advaita Vedanta, is found in the royal collection at Jodhpur, and Bhagvandas's Bhāgavad Gìta Bhāsāa, a commentary/translation of the Bhagavad Gìtā, is found in the royal collection at Jaipur, but since it is unknown when and how these manuscripts came into these collections, it is difficult to say whether they were ever intended for use in the courts, or if they arrived there by accident. $)^{34}$

The dominant stream of thought in modern Hindi scholarship has emphasized the social, religious, and political distance of communities like the Dadu Panth and Niranjani Sampraday from the royal courts of their day, arguing that such bbakti communities, because of their general opposition to the theistic worship of anthropomorphic gods and their images (especially gods associated with the cults of royal courts, like the god-king Ram) and because of their social ideology of spiritual equality across caste distinctions, constituted a challenge to high-caste, religiously orthodox political elites. ${ }^{35}$ The circulation of Dadu Panthi and Niranjani texts at royal courts contradicts this logic and points to yet another type of exchange. This exchange occurred between human representatives of religious and political power, and it was an exchange of religious and political forms of power, through the currency of knowledge, in the material form of the

34 Royal and sub-royal political elites frequently acquired the libraries of other elites through gift, marriage, or conquest; this is seen, for example, in the case of the earliest dated manuscript of Hindi, the Fatehpur manuscript (see the introduction to Bahura and Bryant, Pad Sūrdāsjī $K \bar{a})$.

35 Representative studies include the volume Bhakti Religion in North India: Community Identity and Political Action, ed. David Lorenzen (Albany: State University of New York Press, 1995); and Harinarayan Thakur, Bhārat Meì Picarā Varg Āndolan Aur Parivartan Kā Nayā Samāj-Śästra (Delhi: Kalpaz Publications, 2009), 66-77. The characterization of these religious movements as being positioned in opposition to institutions of religious, social, and political power is certainly not incorrect; the poetic and hagiographical texts of the communities contain powerful critiques of the power structures of their day. Yet the historical realities of the social and political strategies employed by these groups differ somewhat from the ideological positions articulated in their texts. 
manuscript. Political power, in the form of Hindu kingship, was articulated in part through the assertion of moral authority, and an individual's moral authority came about through the study of religious texts. Contemporary encomiums dedicated to Rajput kings praise their study of the scriptures (the Vedas, Puranas, and śāstras) and their corresponding ability to adjudicate legal disputes and dispense justice. Just as important as his moral authority was a ruler's intellectual acumen, in particular his appreciation of and discernment in matters of literature (kävya), music (saingita), and various material and performing arts $(k a l \bar{a})$.

In the context of relatively low levels of literacy in Sanskrit among political elites during this period in North India (or at least the very low levels of production of scholarship in Sanskrit at courts in the region), vernacular intellectuals like the monks of the Dadu Panth and Niranjani Sampraday produced works that gave rulers and their courtiers access to the knowledge systems of Sanskrit, but in literary Hindi, a language in which those rulers and courtiers themselves composed. ${ }^{36}$ For example, the Vedānta Mabāvākya $B \bar{a} \bar{a} s \bar{a}$ of Manohardas presents a selection of important quotations from the Chandogya Upanișad with translations and commentary composed in Hindi verse, providing those unfamiliar with Vedic Sanskrit insight into a foundational text of Advaita Vedanta. Similarly, the Vairāgya Vrnd of Bhagvandas presents the original Sanskrit verses, along with Hindi translations and versified commentary, of the Vairāgya Śataka (One Hundred Verses on Nonattachment) attributed to the legendary poet-king Bhartrihari. This latter text had been, from the medieval period, a primer of sorts for courtly elites: the content of its aphoristic verses educated the reader on ethics, love, and spiritual fulfillment, while the poetic qualities of the verses provided him (or

36 The supposed "decline" or "death" of Sanskrit is a contentious issue that is outside the scope of this essay. As Pollock has pointed out, the centuries immediately preceding the colonial encounter actually saw the production of ingenious works in Sanskrit; see "The Death of Sanskrit," Comparative Studies in Society and History 43, no. 2 (2001): 392-426. See also Sudipta Kaviraj, "The Sudden Death of Sanskrit Knowledge," Journal of Indian Philosophy 33, no. 1 (2005): 119-42. Yet the textual output in Sanskrit at Rajput courts during this period is clearly miniscule in comparison to the textual output in Hindi, in particular by kings and princes themselves. Prime examples include Jaswant Singh of Marwar (r. 1638-1678), Savant Singh of Kishangarh (r. 1748-1757), and Pratap Singh of Jaipur (r. 1778-1803). 
possibly her) an education in the elements of good literature. Being able to quote verses from such a collection in appropriate contexts was considered an essential skill of the cultivated individual. A work like Bhagvandas's Vairāgya Vrnd thus provided its reader with not only the Sanskrit original verses for memorization but also a "cheat sheet" to explain their meaning (as well as equally well-wrought vernacular equivalents). ${ }^{37}$

In exchange for the monks' service of providing educational material that was central to the construction of royal authority, political elites-from Rajput kings to their "lesser" cousins, who as local lords presided over the collection of tax revenue and maintained law and order in the parganas or districts of the kingdom-provided tax-free land grants to religious communities and sometimes even provided funds for the building of monasteries and other sectarian construction projects. The "headquarters" or central monastic branches of both the Dadu Panth and Niranjani Sampraday were built on such land grants, and in the case of the Dadu Panth, a number of the buildings, gates, and tanks in the central monastic complex can be attributed to the patronage of particular Rajput and Mughal elites. ${ }^{38}$

In the context of this exchange between the brokers of religious power and the brokers of political power, let us return to the object of the manuscript. When a monk like Mangaldas of the Niranjani Sampraday concluded his copying of a treatise on Advaita Vedanta with the words "copied by Mangaldas Niranjani for the reading/study of Sher Singh and Guman Singh, sons of the Great King Vijay Singh," he was marking the paper manuscript as a token or receipt of exchange-that is, the exchange of intellectual and political power. If we read the colophons of such manuscripts in light of what we know about such relationships of patronage and power, then we see that the listing of the scribe's teacher-disciple lineage, and the royal lineage of the

37 For more on these types of commentary, see Tyler Williams, "Commentary as Translation: The Vairāgya Vrnd of Bhagvandas Niranjani," in Text and Tradition in Early Modern North India, ed. Tyler Williams, Anshu Malhotra, and John S. Hawley (New Delhi: Oxford University Press, 2018), 99-125.

38 On early building projects and patronage in the Dadu Panth, see the first volume of Narayandas, Śri Dādū Panth Paricay. On the construction of the Niranjani center at Didvana, see Williams, Sacred Sounds and Sacred Books, 153-54. 
king, tied both together into a relationship of interdependence that was imagined to stretch across generations. Notations of the date and location of the manuscript's completion mark a historical expression of alliance, and not just fealty, since monks like Mangaldas Niranjani found themselves in competition with other sectarian traditions for the crown's economic supportagain, in the form of tax-free land grants and subsidization of building projects - and for its symbolic patronage: for if the hagiographies of the period, filled as they are with stories of saints ministering to kings, teach us anything, it is that claiming a royal figure as one's disciple was an important way of increasing the prestige of one's sect, and thus served as a "marketing tool" for recruiting disciples. ${ }^{39}$ And if the manuscript moved between different royal collections-a not infrequent occurrence, as noted above-then a colophon acted as a note to potential future readers (and potentially powerful future readers) of who was responsible for the creation of the manuscript, and therefore of whom one should go to for good copies of good scholarship.

In summary, colophons and other paratexts in scholastic manuscripts mark moments of not only intellectual but sometimes also social, political, and economic exchange. These exchanges of knowledge-for labor, for monetary currency, for social and political prestige and influence-constituted intellectual networks across sectarian, social, political, and sometimes regional boundaries. For example, the scholastic works of Niranjani monks made their way into the collections of the Dadu Panth monasteries in Rajasthan, of Rajput courts in the region (including the powerful courts of Amber/Jaipur and Jodhpur/Nagaur), of wealthy local merchants, and even of some communities outside of the region, like Sikh communities in the Punjab. ${ }^{40}$ And this movement of texts was not unidirectional: manuscript copies of religious

39 The hagiographical texts of the Dadu Panth and Niranjani Sampraday illustrate this point beautifully, as they record their respective saints' service to both royal and merchant communities. For the titles of these hagiographies and their dates, see below. On the fierce competition between religious sects for human and financial resources in early modern north India, see Richard Burghart, “The Founding of the Ramanandi Sect," Etbnobistory 25, no. 2 (1978): 121-39.

40 For example, one finds in Punjab manuscripts of Niranjani works copied together with Sikh texts in the Gurmukhi script. MSS 1428 and M-105, AC Joshi Library, Punjab University, Chandigarh. 
scholarship by Dadu Panthi saints, literary scholarship by the court poet Keshavdas, and hagiographical works by monks of the Ramanandi Sampraday all made their way into the hands of Niranjani religious teachers, having been copied most often (but not exclusively) by Niranjani scribes. Tracing the movement of these texts, we begin to see the broad outlines of an intellectual network in which monastic, non-monastic, courtly, non-courtly, Sanskrit-conversant, and Sanskrit-agnostic vernacular intellectuals exchanged texts and ideas. The heterogeneity of these agents and their sectarian and social locations tells us that their intellectual world did not necessarily observe the distinctions of religious/courtly, cosmopolitan/vernacular, and elite religion/subaltern religion that have become so familiar (and often uncritically so) in modern scholarship on this period in South Asian history.

\section{Reception and Performance}

At present, it is difficult to draw many conclusions about how these material texts were used in pedagogical (or other) contexts because of (1) a general absence of notation and other markings on the manuscripts themselves and (2) the scarcity of documentary sources that mention or describe such performance contexts in any detail. The lack of notation on these manuscripts is itself remarkable in that it contrasts so sharply with the case of contemporary manuscripts from Islamicate scholastic contexts. Manuscripts that circulated in contexts of Islamic learning in the languages of Persian, Arabic, and indeed in literary dialects of Hindi written in the Perso-Arabic script dating to the seventeenth and eighteenth centuries often include notes made by their readers. These notes included references to other works, citations appended to quotations or statements in the text, lines of poetry, quotations, and other textual information that, occasioned by something in the text, came to the mind of the reader. ${ }^{41}$ As such, they are an invaluable

41 An excellent example of such notation in a work of Hindi copied in Perso-Arabic script is provide by Shantanu Phukan in “Through Throats Where Many Rivers Meet': The Ecology of Hindi in the World of Persia," Indian Economic and Social History Review 38, no. 33 (2001): 33-58. 
source for reconstructing precolonial reading and intellectual practices. Rarely does one find such traces of intellectual operations in the folios of the potbi manuscripts considered here. So where and how were those intellectual operations carried out?

Scattered references and descriptions from texts and paintings provide us with some circumstantial evidence on which to hypothesize modes of performance and pedagogy. The hagiographies of the founding saints of the Dadu Panth and Niranjani Sampraday-the Dādū Janm Lìlā (Divine Play of the Life of Dadu, 1620) of Gopaldas, the Dayāl $J_{\bar{\imath}} K \bar{\imath}$ Pañc Paracai (The Five Trials of Dayāl Jī [Haridas], ca. 1738-79), and the Paracai (Trials of [Haridas], ca. 1800) of Raghunathdas all describe meetings of lay devotees in which the religious leader would teach extemporaneously; when the leader passed, his disciples (monks) would continue his ministry to the lay devotees, but were provided with written copies of the founder's poetry from which to teach. ${ }^{42}$ Monika Horstmann has characterized the bound gutkēs that such monks copied as "vademecums" containing epigrams as well as hymns that would anchor the monk's otherwise extemporaneous teaching: each poem provided an occasion and framework for an improvised sermon (pravacan) on a topic (such as greed, liberation, lust, non-attachment, etc.). ${ }^{43}$ This paints a rough picture of the scene of monks' ministering to lay followers, emphasizing the written text's role as a memory prosthetic used

42 Jangopal, Dādū Janm Lìlā (The Divine Play of Dadu's Life), ed. Winand Callewaert as The Hindi Biography of Dadu Dayal (Delhi: Motilal Banarsidass, 1988). Hariramdas, Dayāl jì K⿳亠丷⿵ Pañc Paracai (The Five Trials of Dayāl Jì) of Hariramdas, composed between 1738 and 1779; Rajasthan Oriental Research Institute Jodhpur MS 24778, dated 1817 CE. Raghunathdas, Paracai, in Mangaldas, Śrī Mabārāj Haridāsjì Kì Vāṇ̄, 217-42. The Sant Guṇ Sāgar (Sea of the Virtues of the Saints, 1604?) of Madhavdas relates how, upon the death of Dadu, his son and successor "admonished and reminded every Sant that he should keep a scripture." Verse 25.5, quoted in Monika Horstmann, "Dādūpanthi Anthologies of the Eighteenth and Nineteenth Centuries," in Bhakti in Current Research: Proceedings of the Ninth International Conference on Early Devotional Literature in New Indo-Aryan Languages, Heidelberg, 23-26 July 2003, ed. Monika Horstmann (New Delhi: Manohar, 2006), 167-69.

43 Horstmann, "Dādūpanthi Anthologies of the Eighteenth and Nineteenth Centuries," 164, 173-76; Horstmann, "The Example in Dadupanthi Homiletics," in Orsini and Schofield, Tellings and Texts, 31-59. 
sparingly to anchor or occasion oral and improvised discourse. But the scholastic texts in question here-works of Advaita Vedanta, scriptural commentary, literary theory-were probably not intended for lay devotees; rather, they were intended for educated monks. Furthermore, it seems unlikely that the pothis containing these works-relatively large, unbound, delicate, and somewhat unwieldy in their bastās-were carried around by monks who were constantly on the move. (The aforementioned gutkās or vademecums were much better suited to this purpose.) So where and how were the potbis used?

For this question, sources and scholarship regarding other textual genres of the period may provide some help. In particular, performance practices related to the Sanskrit purānās (a type of compendium of mythical and historical narratives, genealogies, cosmologies, and geographies) and to the Rāmcaritmānas (ca. 1600) of Tulsidas (an immensely popular retelling of the epic of Rama in one of the literary dialects of Hindi) suggest possible ways in which scholastic manuscripts may have been "used." The comparison seems particularly promising because the purānas and Rāmcaritmānas circulated in pothis quite similar to those of these scholastic works in Hindi. In the cases of both the Sanskrit purānas and the Hindi Rāmcaritmānas, portions of the written text were indeed "read aloud" from the page, but the recitation of each portion, be it a verse, a short lyric, a vignette, or just a line, was used as an occasion for an extended exegesis and homily in the vernacular. ${ }^{44} \mathrm{~A}$ work was never read from beginning to end in one sitting; rather its recitation, often occurring over several days, was transformed into a journey during which the listeners often stopped with the professional

44 See Rosalind O’Hanlon, "Performance in a World of Paper: Puranic Histories and Social Communication in Early Modern India," Past \& Present 219, no. 1 (2013): 87-126; Philip Lutgendorf, The Life of a Text: Performing the Rämcaritmānas of Tulsidas (Berkeley: University of California Press, 1991), in particular chapter 3, “The Text Expounded: The Development of Manas Katha." On contemporary performance of the purānas, see McComas Taylor, Seven Days of Nectar: Contemporary Oral Performance of the Bhāgavatapurāna (New York: Oxford University Press, 2016). 
reciter on the side of the main narrative path to ponder some scene or event at length.

Visual and material aspects of scholastic manuscripts in Hindi suggest that they were used in a similar fashion. Their material was organized and visually marked in such a manner as to aid the user in the type of textanchored yet extemporaneous discourse described above. Let us take, for example, MS 26579 of the Rajasthan Oriental Research Institute Jodhpur, a copy of the Vedānt Mabāvākya Bhāṣā completed in 1797 by the monk Jairamdas (fig. 6). As mentioned earlier, the text presents the most famous metaphysical propositions of the Sanskrit Chandogya Upanisad along with vernacular translation and commentary. Jairamdas (or a subsequent user of the manuscript) has used bingul powder to highlight the original Sanskrit verses; vernacular verses that summarize the meaning of the Sanskrit; section headings that designate the topic to be dealt with in the coming verses, or indicate that the current topic is complete; terms like pakșa (subjectlocus, thesis), vipakșa (counter-case, antithesis), pakșāntare (alternative case), and drsțānta (example, instance), all terms adopted from Sanskrit and used to structure dialectic exposition; the terms praśna (question) and uttara (answer), used to mark questions put forth by a disciple and replies given by a teacher (since the commentary is presented in the form of a dialogue); and of course verse numbers. These highlighted rubrics allow the reader to move quickly between portions of the text and locate particular textual elements. Similarly, Chetandas, the scribe of MS 2165 of the Rajasthan Oriental Research Institute Jaipur, a copy of the Vairāgya Vrnd of Bhagvandas dating to the mid-eighteenth century, used red ink to highlight those paratexts that would have helped the user to navigate the text: in addition to verse numbers, he has highlighted section headings, introductory material in each chapter, and importantly the meter of each verse. Why has he noted and highlighted the metrical form? Although it was common practice to note the meter along with a verse in manuscripts of the period, this serves an extra function in this manuscript: the text itself follows a pattern of (1) Sanskrit "śloka," (2) a Hindi translation in dobā meter, and (3) exegetical commentary in arill, chappay, and kavitt meters. The metrical labels thus allow the user to quickly navigate between the 


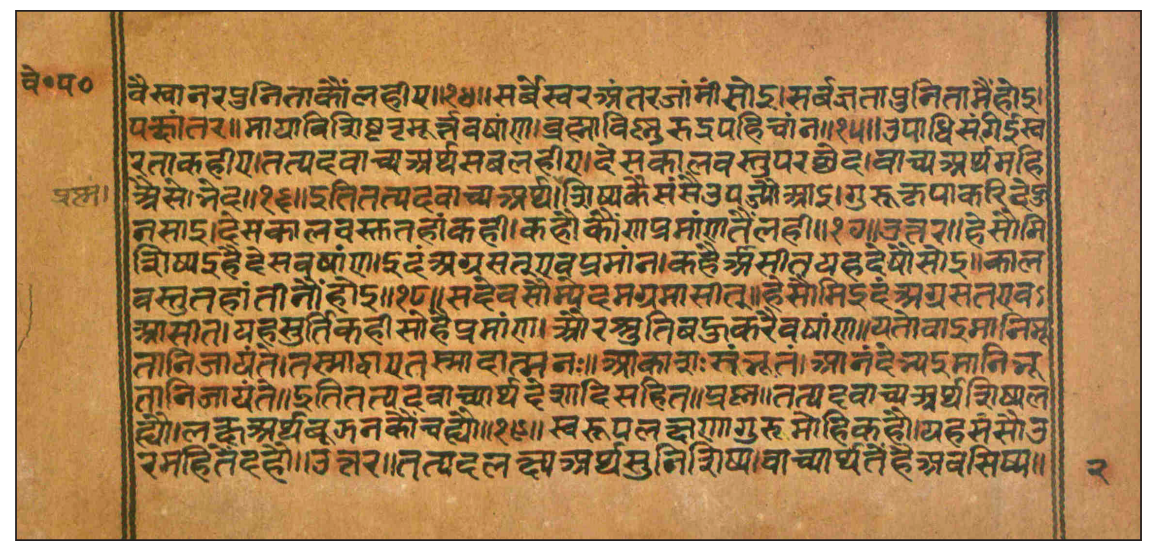

FIGURE 6. Jodhpur, Rajasthan Oriental Research Institute, MS 26579, fol. 2B. The Vedānt Mahāvākya Bhāṣā of Manohardas Niranjani. Manuscript copied in 1797 by the monk Jairamdas.

“original” verse, its literal meaning, and its exegesis—certainly handy for a teacher. ${ }^{45}$

As those familiar with manuscripts of texts from Sanskrit, Prakrit, Apabhramsha, Hindi, Gujarati, Bengali, and other "northerly" vernaculars of the period will no doubt note, these paratexts (and the use of inks and powders to highlight them) are common features, and not particular to any one language or literary tradition. Indeed, "scribes"-which could include monks, scholars, and students, in addition to "professional" scribes that copied texts for a living-often copied texts in multiple languages and transferred scribal conventions from one language into another. ${ }^{46}$ What modern scholars have yet to do on a large scale, however, is to study how

45 It should be noted that this particular copy of the Vairāgya Vrnd is, in regard to format, an exception to the general rule of scholastic manuscripts given above: it is tall and bound on the left edge like a codex. Nevertheless, its other visual elements, like rubrics, follow the general conventions that I have outlined for scholastic manuscripts.

46 I thank Phyllis Granoff for pointing out, during the 2017 Schoenberg Symposium, the frequently mechanical reproduction of scribal practices from Sanskrit in the context of the vernacular (and other languages). 
these paratexts functioned as markers, cues, or guides to oral performance in particular pedagogical, religious, or artistic contexts. ${ }^{47}$ Their function could vary greatly between different literary cultures and performance contexts, and as we have already seen, emerging forms of vernacular genres corresponded to similarly emergent forms and institutions of vernacular scholarship — so we should not always assume that they served the same purpose in vernacular texts as they did in those of Sanskrit, Arabic, Persian, and so on. We can, at the same time, acknowledge that the performance of Sanskrit and the performance of vernacular texts had much in common, as in the case of purānic performance, recitation of the Rāmcaritmānas, and the teaching of the works of religious scholarship considered here.

To return to the question of intellectual networks, these paratextual and material elements point (if sometimes obliquely) to those moments at which an intellectual network extended from the written text through oral/aural performance and into human bodies: during the event of performance in which a guru lectured from a manuscript, the "words of the guru" (guru vacan) imparted knowledge and brought into being an intellectual genealogy (guru-síśya paramparā) between teacher and student. The concept of guru vacan is frequently extolled in the hymns and epigrams of the traditions under consideration here; in contrast, "book learning" is frequently criticized. In the past, modern scholars have frequently misunderstood this as being a critique of written discourse in general; on the contrary, in light of these traditions' copious copying of manuscripts, it would seem that Dadu Panthi and Niranjani monks were criticizing the study of written texts without the mediation of a qualified teacher, a critique (or anxiety) that is familiar not only from medieval Hindu religious writings, but from medieval Islamic writings as well. Consequently, in these traditions' notion of ideal pedagogical practice, the material of the written text, the mediating authority of the teacher, and the curious and receptive intellect of the stu-

47 Essays in the recent volume by Orsini and Schofield, Tellings and Texts, provide an excellent set of arguments for, and guides to, tracing performance practices through traces in the textual and material archive. 
dent come together in the pedagogical event (which is further conditioned by considerations of place, time of day, etc.). As discussed extensively in the sākbi epigrammatic genre employed by the Dadu Panth and Niranjani Sampraday (as well as in longer works like Sundardas's Jñan Samudra), it is through listening attentively to the guru in this context that an individual becomes, in fact, a disciple (śiśya), not merely by being initiated into a monastic organization or by studying "books." Manuscripts thus carry traces of those moments in which they were used in practices that transmitted not only knowledge but also intellectual authority (and thus also sectarian identity), the moments in which budding branches of the network were made to grow. (And it is these same branches that are then re-inscribed into manuscripts as the guru-disciple lineages included in colophons.)

\section{Conclusion: Manuscripts, Scholarship, and Exchange}

By periodically shifting our methodological lens and moving back and forth between the perspectives and modes of distant reading on the one hand (including the comparison of metadata for large numbers of manuscripts) and close reading on the other (including the histories of production and circulation of manuscripts of particular works of scholarship), three important aspects of manuscript culture in early modern North India come into focus. First, there existed in this place and time a set of practices and material objects that can be identified, even if only in rough outline, as vernacular manuscript culture, in contrast to the preceding and contemporary manuscript cultures of cosmopolitan languages like Sanskrit, Arabic, and Persian. This vernacular manuscript culture can be distinguished by the use of particular formats and the relationship of those formats to certain textual genres and performance contexts, and by new uses of preexisting paratextual elements. Second, these textual genres themselves-including vernacular śăstra-were being developed, adapted, and changed at the same time that this manuscript culture was coming into being-and this discursive experimentation was both reflected in, and shaped by, the material aspects 
of the manuscripts in which these emergent genres and styles are found. ${ }^{48}$ It is here that we find some of the self-conscious "newness" of the vernacular-for as Allison Busch has demonstrated in the case of early Hindi poets, the purveyors of the vernacular were only too aware of the novelty of their intellectual and cultural project. ${ }^{49}$

Third, the manuscripts of scholarly works discussed here functioned as markers of several different types of exchange that are both discursive and material in nature. They could mark an exchange of labor for knowledge or tutelage between a student and teacher; an exchange of knowledge for economic or logistical support between a monk and a lay devotee of a religious community; an exchange of religious knowledge for political patronage or social prestige between a religious leader and an agent of royal power; and of course a simple exchange of labor for monetary compensation between a professional scribe and a client. Paratextual elements such as the scribe's signature, teacher-student lineage, name of patron, and place and time of copying commemorate, sanctify, and locate these moments of exchange in historical time. In this respect, manuscripts of scholarship in Hindi mirrored conventions in the manuscript cultures of Sanskrit, Arabic, Persian, and other vernaculars of the time, where we also find such markers of exchange. This commonality once again draws our attention to the multilingual literary context of early modern North India, where vernacular literary and manuscript culture developed not in isolation from, but as the

48 At the 2017 Schoenberg Symposium, Jinah Kim suggested in her paper titled "Intersections of Indic and Chinese Manuscript Cultures: On Hybrid Manuscripts from Nepal and Dunhuang" that unusual formats or elements can sometimes reflect a moment of intercultural encounter, shift, or crisis. This would seem to apply to case of Hindi, which is characterized in its early manuscript history by experimentation with numerous forms, reflecting the emergence of new literary forms.

49 Allison Busch, "The Anxiety of Innovation: The Practice of Literary Science in the Hindi Riti Tradition," Comparative Studies of South Asia, Africa and the Middle East 24, no. 2 (2004): 45-59. See also the first and third chapters of Busch's Poetry of Kings: The Classical Hindi Literature of Mughal India (New York: Oxford University Press, 2011). The question of "how newness enters the world," whether in the context of literature or of culture at large, is another productive problematic introduced by Pollock that has concerned scholars of South Asian literature for the last several years. See The Language of the Gods, 283-98. 
result of constant exchange with, the other literary and manuscript cultures with which it shared geographical, social, and cultural space.

Fourth and finally, as markers of different types of exchange, these manuscripts make visible to us a network of vernacular intellectuals that was emerging during the early modern period in the richly multilinguistic and religiously diverse literary and scholastic landscape to which I have just alluded. This network was partly constituted through the movement of paper manuscripts between religious sects, royal courts, and wealthy individuals, and partly through the oral pedagogical performance by teachers that employed these manuscripts. In this respect, the written/inscriptional and oral/performative "lives" of the scholastic works contained within these manuscripts appear to be inextricable, and thus the embodied, social aspect of the network itself appears no less important than its intellectual "content." 


\section{List OF MANUSCRIPTS CITED}

Baltimore, Walters Art Museum

W.527: 374 n. 33

W.530.A: 374 n. 33

W. $531: 374$ n. 33

W.838: 358, 360, 362, 362 fig. 5 , 364

table 1, 365-77, 380-2

W.839: 358, 360, 361 fig. 4, 362, 365-77, 370 n. $29,380-2$

W.840: 358, 360, 360 fig. 3, 365-77, 370

n. $29,380-2$

Boru Śəllase Monastery

Gospels of Boru Śllase: 367, 367 n. 17, 369-72, 373 fig. 7, 374-82, 376 fig. 8, 378 fig. 9

Cambridge, MA, Harvard University, Houghton Library MS Eng. 1014: 306, 316-17, 317 n. 38, 320, 330

MS Richardson 28: 441 n. 12, 442 n. 14

Chandigarh, Punjab University, AC Joshi

Library

MS 1428: 292 n. 39

MS M-105: 292 n. 39

Cleveland, Cleveland Museum of Art 1942.1511: 374 n. 33

Däbrä Hayq Hsțifanos Monastery

Gospels of Iyäsus Mo'a: 377-78, 377 n. 40, 379 fig. 10, 381

Däbrä Täamina Monastery

Gospels of Däbrä Tä’amina: 367, 367 n. 18, 369-72, 372 fig. 6, 374-75, 381-82
Dublin, Trinity College Library

MS 58: 366 n. 10

Edinburgh, National Library of Scotland MS Hawthornden 2064: 306, 318, $318 \mathrm{n}$. 41, 320-21, 330-31

Florence, Biblioteca Medicea Laurenziana Plut. 1.56: 374 n. 33, 422

The Hague, National Library of the

Netherlands

MMW 10 A 19: 412, 412 n. 57

Jaipur, Maharaja Sawai Singh II Museum MS 2440.28: 288, 288 n. 33

Jaipur, Rajasthan Oriental Research Institute MS 2165: 296

Jodhpur, Rajasthan Oriental Research

Institute

MS 24778: 294 n. 42

MS 26094: 286-87

MS 26334: 277 fig. 3

MS 26579: 296; 297 fig. 6

MS 27518: 284 fig. 4

Leiden, Rijksuniversiteitbibliothek

BPL 108: 435

BPL 111: 435

Scaliger 38: 435

London, British Library

MS 2 B I: 398, 399 fig. 10, 407, 410

MS Add. 5111: 374 n. 33

MS Add. 62925: 403-4, 405 fig. 13

MS Cotton Nero A.x: 383-90, 383 n. 1, 384 n. 3, 388 fig. 1, 389 fig. 2, 390 fig. 3, 
391 fig. 4, 391 fig. 5, 392 fig. 6, 392-407, 394 fig. 7, 395 fig. 8, 401 fig. 11, $406 \mathrm{f}$ ig. 14,408 n. 48, 408 n. 49, 409-20, 411 fig. 15

MS Egerton 1070: 401 n. 32

MS Harley 364: 306, 317, 317 n. 39, 320

MS Harley 966: 305

MS Harley 967: 302, 306

MS Harley 2292: 306

MS Harley 5903: 311 n. 30

MS Harley 5906b: 311 n. 30

MS Harley 5908: 311 n. 30

MS Harley 5909: 311 n. 30

MS Harley 5910: 311 n. 30

MS Harley 5914: 311 n. 30

MS Harley 5915: 311 n. 30

MS Harley 5916: 311 n. 30

MS Harley 5917: 311 n. 30

MS Harley 5918: 311 n. 30

MS Harley 5919: 311 n. 30

MS Harley 5920: 311 n. 30

MS Harley 5921: 311 n. 30

MS Harley 5922: 311 n. 30

MS Harley 5923: 311 n. 30

MS Harley 5924: 311 n. 30

MS Harley 5925: 311 n. 30

MS Harley 5926: 311 n. 30

MS Harley 5927: 311 n. 30

MS Harley 5928: 311 n. 30

MS Harley 5929: 311 n. 30

MS Harley 5930: 311 n. 30

MS Harley 5931: 311 n. 30

MS Harley 5932: 311 n. 30

MS Harley 5933: 311 n. 30

MS Harley 5934: 311 n. 30

MS Harley 5935: 311 n. 30

MS Harley 5936: 311 n. 30

MS Harley 5937: 311 n. 30

MS Harley 5938: 311 n. 30

MS Harley 5939: 311 n. 30

MS Harley 5940: 311 n. 30

MS Harley 5941: 311 n. 30

MS Harley 5942: 311 n. 30
MS Harley 5943: 311 n. 30

MS Harley 5944: 311 n. 30

MS Harley 5945: 311 n. 30

MS Harley 5946: 311 n. 30

MS Harley 5947: 311 n. 30

MS Harley 5948: 311 n. 30

MS Harley 5949: 311 n. 30

MS Harley 5950: 311 n. 30

MS Harley 5951: 311 n. 30

MS Harley 5952: 311 n. 30

MS Harley 5953: 311 n. 30

MS Harley 5954: 311 n. 30

MS Harley 5956: 311 n. 30

MS Harley 5957: 311 n. 30

MS Harley 5958: 311 n. 30

MS Harley 5959: 311 n. 30

MS Harley 5960: 311 n. 30

MS Harley 5961: 311 n. 30

MS Harley 5962: 311 n. 30

MS Harley 5963: 311 n. 30

MS Harley 5964: 311 n. 30

MS Harley 5965: 311 n. 30

MS Harley 5966: 311 n. 30

MS Harley 5967: 311 n. 30

MS Harley 5968: 311 n. 30

MS Harley 5969: 311 n. 30

MS Harley 5970: 311 n. 30

MS Harley 5971: 311 n. 30

MS Harley 5972: 311 n. 30

MS Harley 5973: 311 n. 30

MS Harley 5974: 311 n. 30

MS Harley 5975: 311 n. 30

MS Harley 5976: 311 n. 30

MS Harley 5977: 311 n. 30

MS Harley 5978: 311 n. 30

MS Harley 5986: 311 n. 30

MS Harley 5987: 311 n. 30

MS Harley 5988: 311 n. 30

MS Harley 5989: 311 n. 30

MS Harley 5990: 311 n. 30

MS Harley 5991: 311 n. 30

MS Harley 5992: 311 n. 30

MS Harley 5993: 311 n. 30 
MS Harley 5994: 311 n. 30

MS Harley 5995: 311 n. 30

MS Harley 5996: 311 n. 30

MS Harley 5997: 311 n. 30

MS Harley 5998: 311 n. 30

MS Harley 6795: 306

MS Royal 6 E VI: 396, 396 n. 21

MS Royal 6 E VII: 396, 396 n. 21

MS Royal 16 G VI: 403, 403 n. 40, 404

fig. 12

MS Royal 19 B XV: 393 n. 19

MS Sloane 885: 311 n. 30, 312

MS Sloane 1044: 311 n. 30

MS Sloane 1086: 311 n. 30

MS Sloane 1983: 311 n. 30

London, Lambeth Palace Library

MS Arc.L.40.2/E.23: 307

MS Arc.L.40.2/E.25: 307

MS Arc.L.40.2/E.64: 308 n. 22

MS Sion L40.2/E24: 307-8, 309 fig. 1, 312-15, 316 fig. 2, 318-19, 321-29, 325

fig. 3, 328 fig. 4, 331-33, 331 n. 50, 332 fig. 5

London, University College London

Library

MS Ogden 7: 305 n. 13

Los Angeles, J. Paul Getty Museum

MS 33: 413-14, 413 fig. 16

MS 89: 370-71, 370 n. 31

Manchester, John Rylands Library

Hindustani MS 1: 275 fig. 2

Rylands French 142: 406-7, 407 n. 43

Maynooth, Russell Library

RB36: 431-32, 432 fig. 1, 433 fig. 2, 436, 438

Mehakelegnaw, Abba Garima Monastery

Gärima I: 363, 363 n. 4, 363 n. 5, 366

n. $10,367-68$

Gärima II: 363 n. 4, 363 n. 5, 366, 366

n. 10,367
Gärima III: 363, 363 n. 4, 363 n. 5, 366, 366 n. 10, 367-68

Naples, Università degli Studi di Napoli

L'Orientale

MS ARA 30: 340 n. 14, 342 n. 21, 343 n.

24, 344 n. 28,347 n. 37, 356

MS ARA 50: 340 n. 14, 340 n. 15, 342 n.

21, 344-45, 344 n. 27, 345 n. 29, 345 n.

30, 345 n. 31, 347 n. 37, 356

MS ARA 51: 356

MS ARA 71: 340 n. 14, 343 n. 24, 347 n.

37, 356

MS ARA 93: 340 n. 15, 343 n. 24, 356

MS ARA 259: 345 n. 30, 345 n. 31, 347

n. 37,356

MS ARA [no shelfmark] "Kitāb al-jawāhir al-muntaqāt”: 345 n. 30, 345 n. 31, 347 n.

37,356

MS ARA [no shelfmark] "Fiqh Ibāḍite": 347 n. 37,356

New York, Metropolitan Museum of Art

57.185.3: 425-26, 427 fig. 2

New York, Morgan Library and Museum MS M.639: 374 n. 33

MS M.828: 363 n. 4, 367, 367 n. 15, 369

n. 28,378 n. 43,381 n. 53

MS M.1078: 396, 397 fig. 9, 409 n. 52

MS M.1112: 425-26, 427 fig. 2

Newark, NJ, Newark Museum

Coll. 96.46.1: 357-58, 358 fig. 1, 365-77, 375 n. 35, 380-82, 380 n. 46-51

Coll. 96.46.2: 357-58, 359 fig. 2, 360, 362, 364 table 1, 365-77, 380-82

Oxford, Bodleian Library

MS Ashmole 792: 306, 312 n. 32

MS. Eng. poet. a. 1: 398, 398 n. 28

MS Junius 11: 396, 396 n. 20

Oxford, Queen's College Library

MS 251: 306, 313, 317-18, 318 n. 40, $320,330,333$ 


\section{Journal For Manuscript Studies}

Paris, Bibliothèque Nationale

MS Éthiopien 32: 365 n. 7, 367-68, 368 n. 18

MS. lat. 964: 435, 435 n. 6

MS. lat. 4892: 435

MS. lat. 5019: 435

MS. lat. 9435: 435

Philadelphia, University of Pennsylvania

MS Codex 85: 442-69, 442 n. 15, 443

n. 16,443 n. 17,443 n. 20,444 n. 21,444

n. 22

MS Codex 736: 441-42, 441 n. 12, 442

n. 14

MS Coll. 390, Item 42: 483

MS Coll. 390, Item 178: 480

MS Coll. 390, Item 292: 484 n. 28

MS Coll. 390, Item 497: 482 n. 25

MS Coll. 390, Item 533: 483, 483 fig. 4

MS Coll. 390, Item 890: 474 n. 10

MS Coll. 390, Item 893: 474 n. 10

MS Coll. 390, Item 896: 474 n. 10

MS Coll. 390, Item 1136: 479 n. 18

MS Coll. 390, Item 1334: 479 n. 19

MS Coll. 390, Item 1567: 482

MS Coll. 390, Item 1783: 485

MS Coll. 390, Item 2053: 484 n. 28

MS Coll. 390, Item 2172: 480

MS Coll. 390, Item 2615: 480, 481 fig. 3

MS Coll. 390, Item 2660: 480

MS Coll. 390, Item 2670: 475 n. 13

MS Coll. 390, Item 2671: 475 n. 13

MS Coll. 390, Item 2672: 475 n. 13

MS Coll. 390, Item 2673: 475 n. 13

MS Coll. 390, Item 2674: 475 n. 13

MS Coll. 390, Item 2675: 475 n. 13

MS Coll. 390, Item 3020: 474

MS Coll. 390, Item 3045: 483

MS Indic 2: 476 n. 15
MS Indic 6: 476 n. 15

MS Indic 10: 274 fig. 1

MS Indic 26: 475 n. 13

MS Indic 28: 275 n. 15

Rossano, Rossano Cathedral, Diocesan

Museum

GA 042: 374 n. 33,422

Šemazānā, Akkala Guzāy, Däbrä Libanos

Monastery

Gospel of Däbrä Libanos: 365 n. 6

Təgray, Church of Qärsäbär Mika’el

Gospels of Qärsäbär Mika'el: 371 n. 32

Vatican City, Biblioteca Apostolica Vaticana

Pal. Gr. 220: 374 n. 33

Vat. Gr. 364: 374 n. 33

Venice, San Lazzaro, Mekhitarist Library

MS 1400/108: 374 n. 33

Vienna, Österreichische Nationalbibliothek Cod. Suppl. Gr. 52: 374 n. 33

Washington, D.C., U.S. Library of

Congress

MS 1-85-154.77: 276 n. 16

Yerevan, Matenadaran

MS 238: 422 n. 4

MS 974: 423, 424 fig. 1, 425

MS 2877: 422 n.4

MS 2930: 422 n. 4

MS 3784: 423 n.6

MS 4813: 423 n.6, 426, 428 fig. 3, 429

MS 4818: 422 n. 4

MS 7456: 422 n. 4

MS 7736: 422 n. 4

MS 9423: 422 n.4

MS 10780: 422 n.4 